\title{
THE LOWER CRETACEOUS TIRGAN FORMATION IN THE GELIAN SECTION (KOPET DAGH, NORTH IRAN): MICROFACIES, MICROFOSSILS, AND THEIR BIOSTRATIGRAPHIC SIGNIFICANCE
}

\author{
Ioan I. Bucur ${ }^{1 *}$, Hamed Yarahmadzahi ${ }^{2}$ \& Cristian V. Mircescu ${ }^{1}$
}

Received: 06 February 2019 / Accepted: 13 February 2019 / Published online: 15 February 2019

\begin{abstract}
The carbonate succession of the Tirgan Formation was studied in the Gelian section located $25 \mathrm{~km}$ south of Shirvan town (central Kopet Dagh). In this section, the Tirgan Formation contains a rich assemblage of calcareous algae and foraminifera. Based mainly on the orbitolinid association a latest Barremian-ealy Aptian age was assigned to the Tirgan Formation in the Gelian section. Based on the available stratigraphic analyses and age assignments of the overlying Sarcheshmeh Formation by different authors, one should presume that both the Tirgan and the Sarcheshmeh formations are heterochronous across the Kopet Dagh basin.
\end{abstract}

Keywords: Calcareous algae, Foraminifera, heterochrony, Kopet Dagh, Iran

\section{INTRODUCTION}

The Kopet Dagh basin is well known for its hydrocarbon potential. Several previous studies focused on its structure and stratigraphic succession (Afshar Harb, 1979; Ruttner, 1991; Moussavi-Harami and Brenner, 1993; Immel et al., 1997; Majidifard, 2003; Kavoosi et al., 2009; Javanbacht et al., 2011; Robert et al., 2014; Majidifard et al., 2017).

In the last decades, important contributions addressed the microbiostratigraphy of the Lower Cretaceous Tirgan Formation (Majidifard, 2003; Bucur et al., 2013; Taherpour Khalil Abad et al., 2009; 2010a, 2010b, 2013, 2015; Taherpour Khalil Abad, 2017: Yavarmanesh et al., 2017). Important thickness and content variations define this formation throughout the basin, as indicated by literature data. Additional studies performed on novel geological sections can contribute to a better understanding of its geological depositional context. The present study aims to describe the succession of the Tirgan Formation in the Gelian section. New micropaleontological data including calcareous algae and benthic foraminifera are reported, for correlation purposes with other sections of this unit from the Kopet Dagh basin.

\section{LOCATION AND GEOLOGICAL FRAMEWORK}

The Kopet Dagh thrust and fold belt has a total length of more than $600 \mathrm{~km}$. It stretches along the IranTurkmenistan border (Stoecklin, 1968; Afshar Harb, 1979) (Fig. 1). Following the Paleotethys closure at the end of the Triassic (old Cimmerian movements), the opening of the Kopet Dagh Basin started in the Middle Jurassic. Its sedimentary succession consists of over $10000 \mathrm{~m}$ thick Mesozoic and Cenozoic deposits (Afshar Harb, 1979; Brunet et al., 2009; Fürsich et al., 2009; Wilmsen et al., 2009).

The Lower Cretaceous succession from the Kopet Dagh basin comprises five distinct units: the Surijeh, Tirgan, Sarcheshmeh, Sanganeh and Aitamir formations (Afshar Harb, 1979). A relatively thick succession of Barremianlower Aptian carbonate platform limestones makes up the Tirgan Formation, overlying the Surijeh Formation and underlying the Sarcheshmeh Formation (Majififard, 2003; Taherpor Khalil Abad et al, 2010a). Thickness distribution patterns indicate a general east-west thickening trend, the unit ranging from $50-100 \mathrm{~m}$ in the east, to over $700 \mathrm{~m}$ in the west (Afshar Harb, 1979).

The present study describes a section located near Gelian locality, $25 \mathrm{~km}$ south of Shirvan town, in the central part of the Kopet Dagh (Fig. 1; Fig.2) (Coordinates: $34^{\circ} 14^{\prime} 14^{\prime \prime} \mathrm{N}$ and $\left.57^{\circ} 54^{\prime} 12^{\prime \prime} \mathrm{E}\right)$. Here, the carbonate succession of the Tirgan Formation (Fig. 3) consists of $153 \mathrm{~m}$ of bioclastic to oolithic limestones with rare marlylimestone intercalations (Fig. 4) containing, mostly in its upper part, orbitolinid foraminifera.

\section{MATERIAL AND METHODS}

Sixty-three samples (G1 to G63) were collected in the Gelian succession, from which standard thin-sections were made (these include 52 samples from limestones of the Tirgan Formation). The thin-sections are housed at the Faculty of Science, Islamic Azad University of Zahedan (Iran).

\section{MICROFACIES}

Four facies associations were identified in the Gelian section, consisting of different microfacies types.

1) The first facies association consists of partially fenestral mudstone and fenestral mudstone-wackestone (Fig. 5a). Some of these microfacies types are distributed within the middle part of the succession (samples G20, G21). They contain small bivalve fragments, rare small forami- 


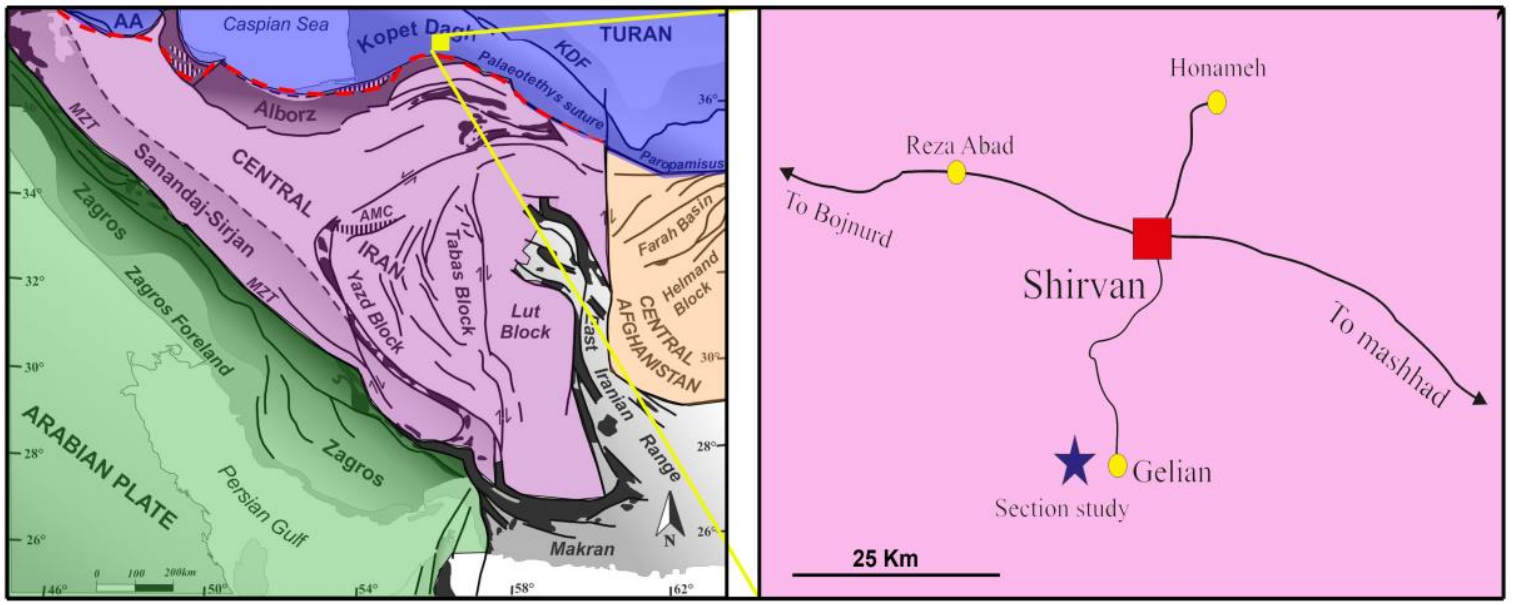

Fig. 1 Location of the studied Gelian section on the Iranian territory and in the area surrounding Shirvan town. Modified from Zanchi et al., 2003.

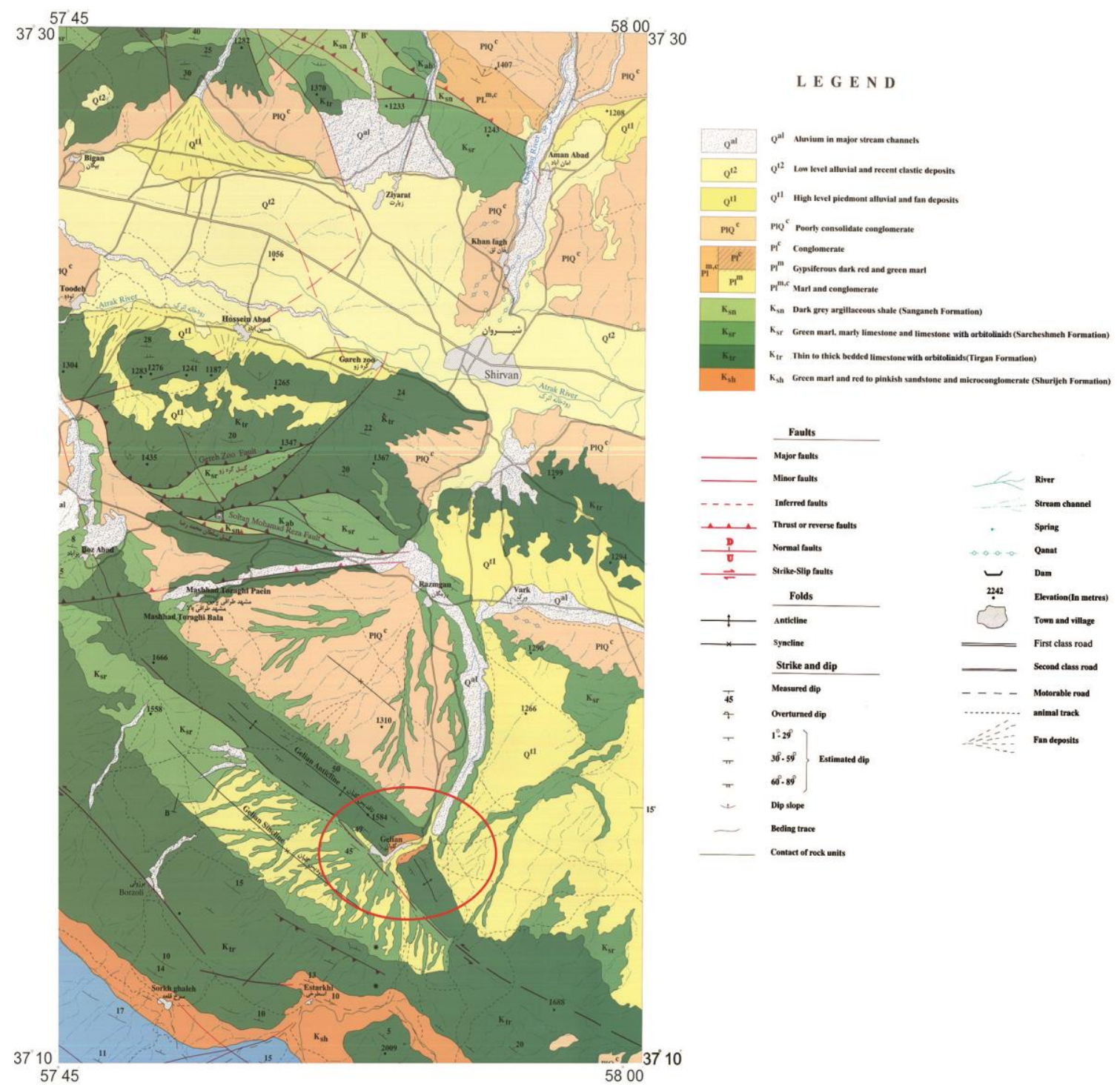

Fig. 2 Geological map of the region surrounding Shirvan town. The location of the Gelian section is indicated by the red circle. Modified from Nadim \& Haftlang, 2009. 


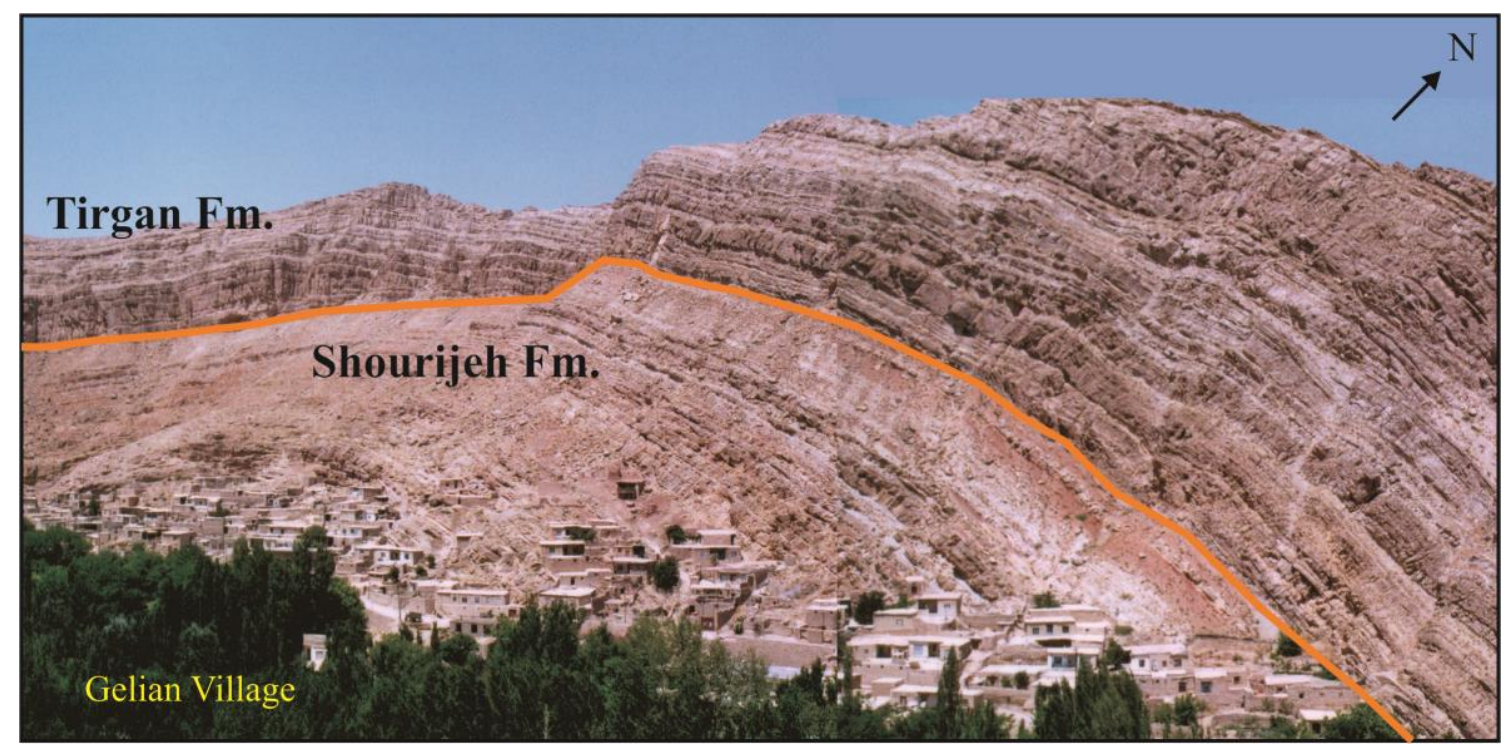

Fig. 3 Field photo showing the contact between the Shurijeh and Tirgan formations in the Gelian area.

nifera and rare dasycladalean algae. In association with some fenestral wackestone microfacies types (sample G22), they indicate an inner platform, restricted lagoonal environment.

2) The second facies association contains different wackestone types: bioclastic wackestone, ooidal-intraclastic wackestone, foraminiferal wackestone, rudist wackestone, fenestral wackestone, bioclastic wackestonepackstone (Fig.5b, d, g). Wackestone facies types are well developed through the entire succession of the Tirgan Formation. They are commonly interbedded with other facies categories and contain a large variety of bioclasts (mollusc, echinoderm and bryozoan fragments, anellid worm tubes, foraminifera, dasycladalean and udoteacean-gymnocodiacean algae). Occasionally, ooids and intraclasts are present. Some fenestral varieties contain Rivularia-type cyanobacteria. They indicate a restricted, inner platform environment. Silty or smallarenitic quartz is present in some varieties. The upper part of the succession contains nodosariid foraminifera indicating a relative deepening of the depositional environment.

3) The third association contains orbitolinid-bearing packstones and bioclastic packstone-grainstone (Fig 5c, e, f). These microtypes are interbedded with other facies categories throughout the entire succession of the Tirgan Formation. They contain a wide range of bioclasts (mollusc, echinoderm and bryozoan fragments, foraminifera, dasycladalean and udoteacean-gymnocodiacean algae). Some varieties contain abundant bryozoans (e.g., sample G38) while others show abundant orbitolinids and dasycladalean algae (samples G29, G45-G47). Worth mentioning are the varieties rich in Balkhania balkhanica Mamontova (sample G18c) (Fig. 5c). Samples G32a and $\mathrm{G} 32 \mathrm{~b}$ consists of packstone with reworked orbitolinids and other bioclasts. These bioclasts show a distinct, welldeveloped micritic rim (possibly of microbial origin). Stylolitic grain contacts and partial iron oxide developments are common. The packstone facies types indicate a moderate to low energy, open marine environment. 4) Finally, the fourth facies association consists of ooidal grainstone, bioclastic grainstone, peloidal-bioclastic grainstone, and bioclastic grainstone-rudstone (Fig. $5 \mathrm{~h}-\mathrm{j}$ ). Bioclast diversity characterises all these facies varieties. The bioclasts include mollusc, echinoderm and bryozoan fragments, anellid worm tubes, foraminifera and calcareous algae, as well as rare coral and sponge fragments. These facies types are also interbedded with other facies types throughout the entire succession of the Tirgan Formation. In the lower part of the succession they contain terrigenous quartz fragments that form the nucleus of some ooids.

The grainstone facies association is typical for relatively shallow, high energy, open marine environments. Some lithological varieties contain meniscus cement and keystone vugs (sample G25), structures indicating a very shallow depositional environment.

The vertical facies distribution within the Tirgan Formation is illustrated in Fig. 6.

The entire carbonate succession of the Tirgan Formation corresponds to a ramp-type carbonate platform, documenting the presence of inner and middle ramp depositional settings for the Gelian section. Small-scale coral and sponge bioconstructions (samples G18b, G23a, $\mathrm{G} 23 \mathrm{~b}$ ) were developing across the carbonate ramp. However, they did not form continuous rims to bar the platform.

\section{Micropaleontological associations and age of the Tirgan Formation in the Gelian section}

The studied succession contains rich assemblages of calcareous algae and foraminifera. Calcareous algae are represented by the following species: Actinoporella podolica (Alth) (Fig. 7a,b), Bakalovaella elitzae (Bakalova) (Fig. 8a-d), Deloffrella quercifoliipora Granier \& Michaud (Fig. 7c-f), Kopetdagaria sphaerica Maslov (Fig. 7g-i), Neomeris cf. cretacea Steinmann (Fig. 8e-h), Neomeris sp. (Fig. 8i-j), Neomeris div. sp. (Fig. 8k-m), Pseudoactinoporella? iranica Bucur, Rashidi \& SenowbariDaryan (Fig. 9a-c), Salpingoporella muehlbergii (Lorenz) (Fig. 9d-g, j; Fig. 10a-c, g, h), Salpingoporella div. sp. 


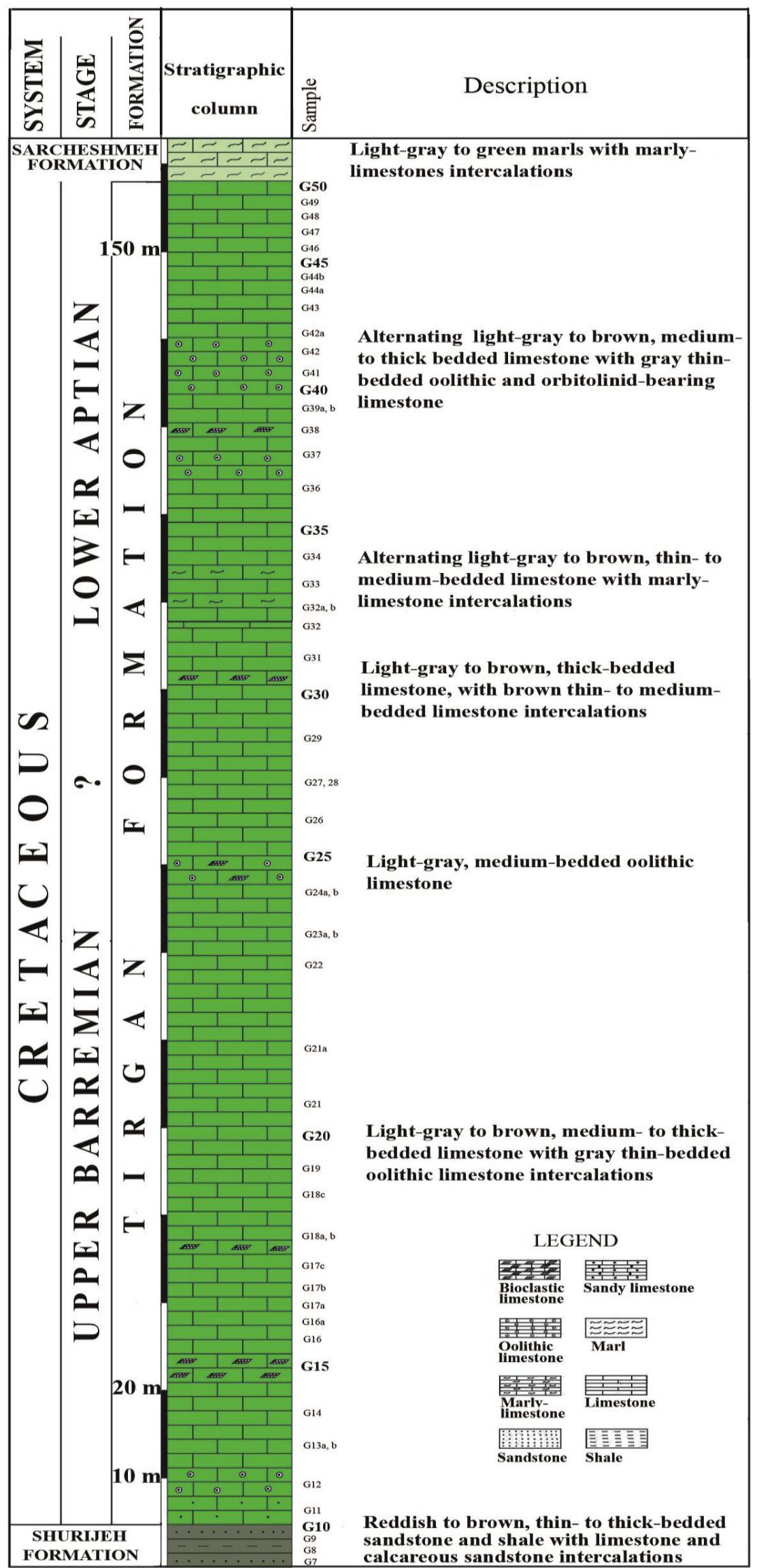

Fig. 4 Succession of carbonate deposits of the Tirgan Formation within the Gelian section 


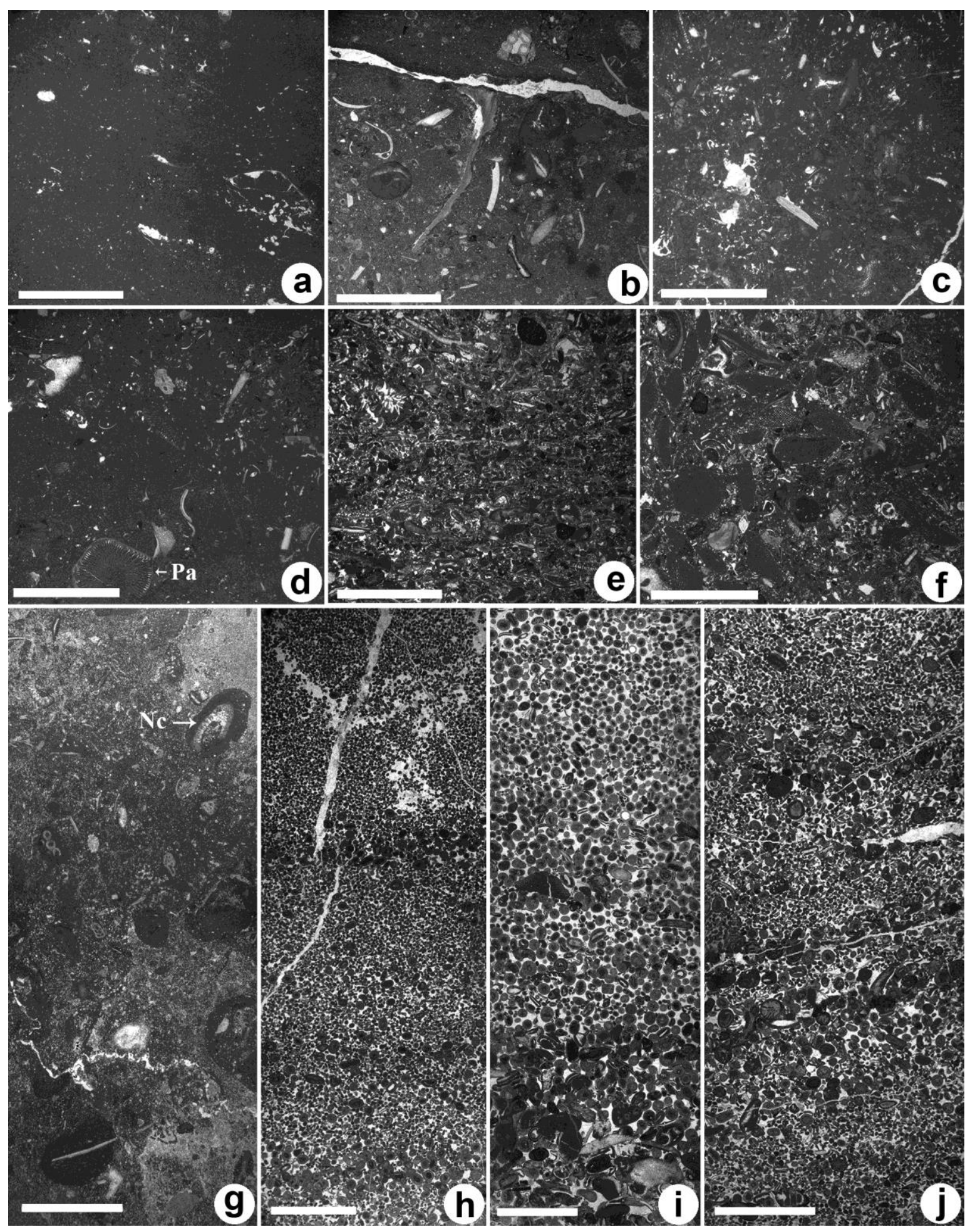

Fig. 5 Microfacies. a Fenestral mudstone with small benthic foraminifera, rare fragments of gastropods and worm tubes, and very rare dasycladaleans; sample G21. b Wackestone with ooids, intraclasts and bioclasts; the matrix is a siltic carbonate containing rare siltic to small arenitic quartz; sample G13A. c Bioclastic packstone with Balkhania balkhanica, fragments of molluscs, rare fragments of echinoderms, and rare ooids, foraminifera and calcareous algae; sample G18C. d Wackestone with fragments of molluscs, echinoderms and bryozoans, rare nodosariid framinifera, orbitolinids $(\mathrm{Pa}=$ Paleodictyonus actinostoma) and dasycladaleans; sample G44B. e Bioclastic packstone with fragments of molluscs, echinoderms and bryozoans, foraminifera (Balkhania balkhanica) and calcareous algae; sample G16A. f Bioclastic packstone with orbitolinids, lenticulinids, fragments of molluscs, worm tubes, echinoderm, bryozoans, and calcareous algae; sample G45. g Wackestone, partly dolomitized, with orbitolinids, fragments of bivalves, echinoderms and bryozoans, dasycladaleans (Nc=Neomeris cf. cretacea) and small fragments of udoteacens; sample G34. h-j Ooidic grainstone, containing ooidic laminae with variable granulometry; frequently, the ooid nuclei are made of bioclasts (foraminifera or bivalve fragments); orbitolinids, as well as mollusc, echinoderm and bryozoan fragments are present; $\mathrm{h}$ - sample G40; $\mathrm{i}$ sample G41; $\mathrm{j}$ - sample G43. Scale bar is $1 \mathrm{~mm}$. 


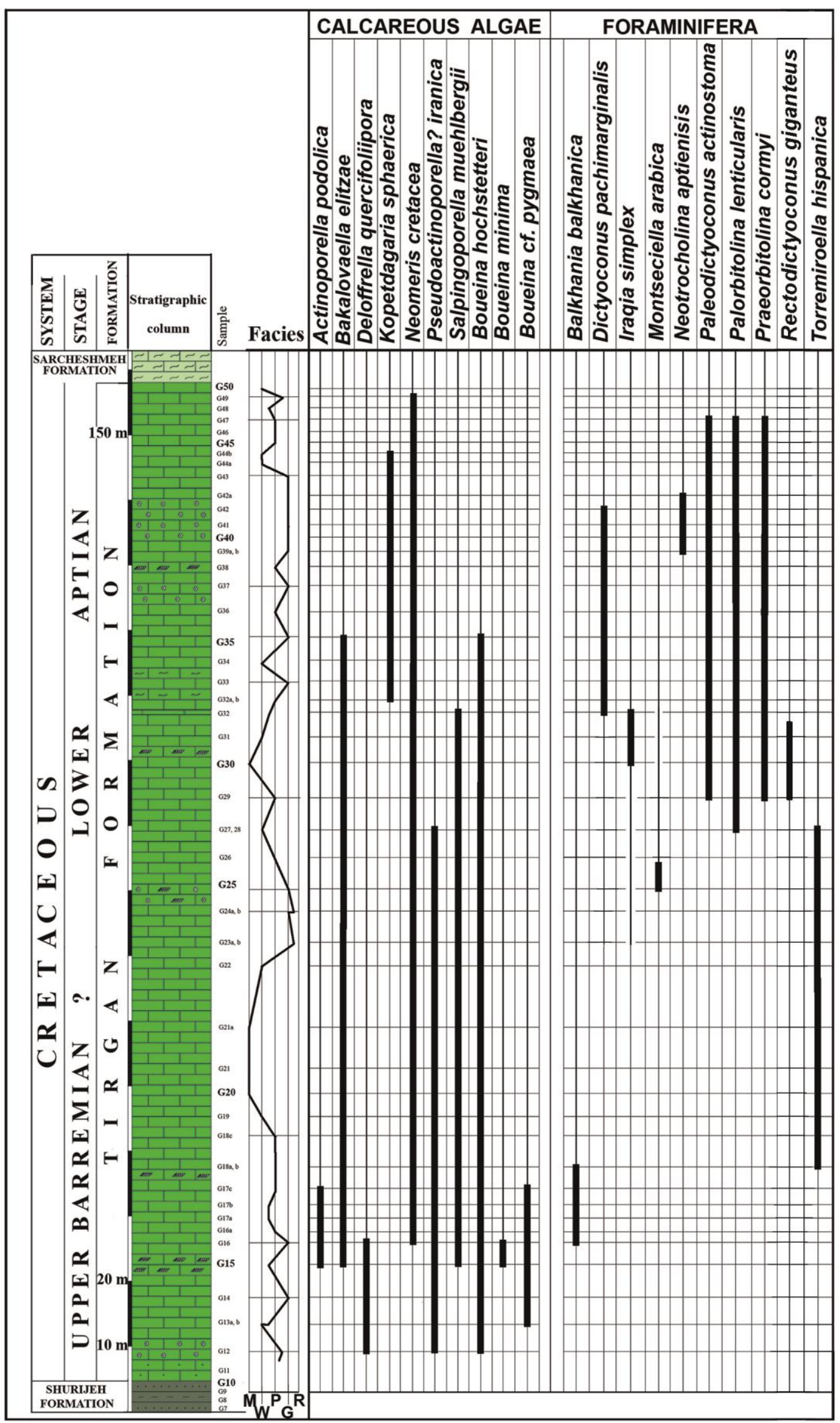

Fig. 6 Stratigraphic range of the main microfossils (calcareous algae and foraminifera) identified in the Tirgan Formation from the Gelian section. 
(Fig. 9h, i; Fig. 10d-f, i-k, n), Steinmanniporella sp. (Fig. 10p), Terquemella div. sp. (Fig. 11a-1), Triploporella sp. (Fig. 10r), ?Zittelina sp. (Fig. 10s), Arabicodium sp. (Fig. 12a, b), Boueina hochstetteri Toula (Fig. 12c; Fig. 13c), Boueina minima Bucur (Fig. 12f, g; Fig. 13d), Boueina cf. pygmaea Pia (Fig. 12h, i; Fig. 13a, b, e-g, i), BoueinaArabicodium-Permocalculus-like udoteaceangymnocodiacean algae (Fig. 12e, j-m), Permocalculus (Pyrulites) deceneii Bucur (Fig. 12d), Permocalculus div. sp. (Fig. 13h, j, k), and Marinella lugeoni Pfender. The foraminiferal association includes the following species: Balkhania balkhanica Mamontova (Fig. 14a-d), Charentia cuvillieri Neumann (Fig. 15a), Dictyoconus? pachymarginalis Schroeder (Fig. 16 e-f), Frentzenella odukpaniensis (Desauvagie) (Fig. 15n, ?o), Iraqia simplex Henson (Fig. 17a, c-e), ?Iraqia sp. (Fig. 17b, f, g, i), Lenticulina sp. (Fig. 15j-m, u), Montseciella arabica (Henson) (Fig. 16b), Neotrocholina aptiensis (Iovtcheva) (Fig. 15p-t), ?Orbitolinopsis sp. (Fig. 16d, g, h), Palaeodictyoconus actinostoma Arnaud-Vanneau \& Schroeder (Fig. 17j-1), ?Palaeodictyoconus sp. (Fig. 16m), Palorbitolina lenticularis (Blumenbach) (Fig. 17h), Praeorbitolina cormyi Schroeder (Fig. 16i-1), Rectodyctioconus giganteus Schroeder (Fig. 16a), Toremiroella hispanica Brun \& Canerot (Fig. 14e-h), and Vercorsella scarsellai (De Castro) (Fig. 14, k, m, n). From these microfossils, the orbitolinids have the most important biostratigraphic significance. Palorbitolina lenticularis is known from upper Barremian to lower Aptian (Bedoulian) deposits (Schroeder et al., 2010). A recent study (Clavel in Granier et al., 2013) lowered its range into the upper part of the lower Barremian. Montseciella arabica is well known from upper Barremian to lowermost Aptian deposits (Masse, 2003; Schroeder et al., 2010), and Iraqia simplex covers the upper Bedoulian (i.e., upper part of the lower Aptian, Masse, 2003; Schlagintweit et al., 2013a). Paleodictyoconus actinostoma was described from the lower Aptian by Arnaud-Vanneau \& Schroeder (1976), and Schlagintweit et al. (2013a) have mentioned this taxon from the upper Bedoulian (the upper part of the lower Aptian). Praeorbitolina cormyi, a taxon with a wide distribution within the Tethyan realm, has a stratigraphic range restricted to the upper Bedoulian (Masse, 2003; Schroeder et al., 2010; Schlagintweit et al., 2013a). Dictyoconus? pachymarginalis was initially described from the Bedoulian-Gargasian boundary (Schroeder, 1965). It is frequently mentioned from uppermost Bedoulian (Mancinelli and Chiocchini, 2006) or upper BedoulianGargasian (Schlagintweit et al. 2013a, 2013b) deposits, and was recently reported from the lower BarremianBedoulian (Yazdi-Moghadam et al., 2017).

The stratigraphic range of the orbitolinids from the Gelian section is consistent with the above-mentioned distributional data (Fig. 6). Based on these microfossils, the age of the Tirgan Formation (Gelian section) is latest Barremian-Bedoulian. The Barremian/Aptian boundary is located approximately in the lower third of the succession.

\section{The age of the Tirgan Formation and the Lower} Cretaceous diachronism in the Kopet Dagh region.

Based on micropaleontological assemblages, the carbona- te deposits of the Tirgan Formation were attributed to the Barremian-lower Aptian by the vast majority of previous authors who studied these limestones. Numerous sections were sampled from West to East across the Kopet Dagh basin, over the entire outcrop surface of the Tirgan Formation (Taherpour Khalil Abad et al., 2009; 2010; 2013; Javanbakht et al., 2011; Carević et al., 2013; Taherpour Khalil Abad et al., 2013; Molaei et al., 2017; Taherpour Khalil Abad, 2017; Yavarmanesh et al., 2017; Javanbakht et al., 2018). Surveying the previously figured micropaleontological assemblages shows that in many of these publications, several species were incorrectly identified (e.g., Carević et al., 2013; Molaei et al., 2017, Yavarmanesh et al., 2017, etc.), with the notable exception of the work of Taherpour Khalil Abad et al. (2009; 2010; 2013). However, the correctly identified micropaleontological assemblages from all of these papers are conform with their attribution to the Barremian-lower Aptian interval. In the case of the Gelian section discussed in this study, a latest Barremian-early Aptian age was inferred. Recently Taherpour Khalil Abad et al. (2017) presented a succession of sampled sections from the Tirgan Formation that document thickness variation within the unit from the central part of the Kopet Dagh $(330 \mathrm{~m})$ towards the east (45 $\mathrm{m})$. In addition, the micropaleontological association of some sections (e.g., Chenaran, Ali Abad) contains Berriasian-Valanginian foraminifera (Anchispirocyclina lusitanica, "Trocholina elongata", Pseudocyclammina litu$u s$ ). Raisossadat \& Moussavi-Harami (2000) and Raisossadat and Shakri (2011) have studied the Sarcheshmeh Formation, a unit overlying the Tirgan Formation. These authors indicate a late Barremian to early Aptian age for the Sarcheshmeh Formation based on ammonites and calcareous nannoplankton. Thus, they assigned a Barremian (but not terminal Barremian) age for the Tirgan Formation. In this context, Arnaud-Vanneau et al. (2017) questioned the previously assigned age of the Tirgan Formation, near its type locality where the succession has a total thickness of about $700 \mathrm{~m}$. According to Arnaud-Vanneau et al. (2017), the basal part of this formation may comprise the Berriasian-Hauterivian, or even part of the upper Tithonian.

Important thickness variations within the Tirgan Formation were already indicated by Afshar Hab (1979), with a maximum thickness reaching 600-700 $\mathrm{m}$ in the central-western part of the basin. The thickness of the formation decreases to 20-35 m towards east, and to 250 $\mathrm{m}$ in the NNW. In the central part of the basin (around the Bojnourd locality), it has a total thickness of $300 \mathrm{~m}$. As pointed out by Afshar Harb (1979), northeast of Moshad the lower part of the Tirgan Formation passes laterally into the Shurijeh Formation, whereas toward the west (Daregaz area, where the type section of the Tirgan Formation is located) deposits of the Shurijeh Formation pass laterally into the carbonates of the lower part of the Tirgan Formation. Afshar Harb (1979) indicated a Barremian to early Aptian age for the Tirgan Formation, and noted that its lower part may also include the Hauterivian near its type locality. The Tirgan Formation becomes younger west and east from this locality, being represented mainly by Aptian deposits. Accordingly, Afshar Harb (1979) assumed a heterochronous contact between the Tirgan Formation and the underlying Surijeh 

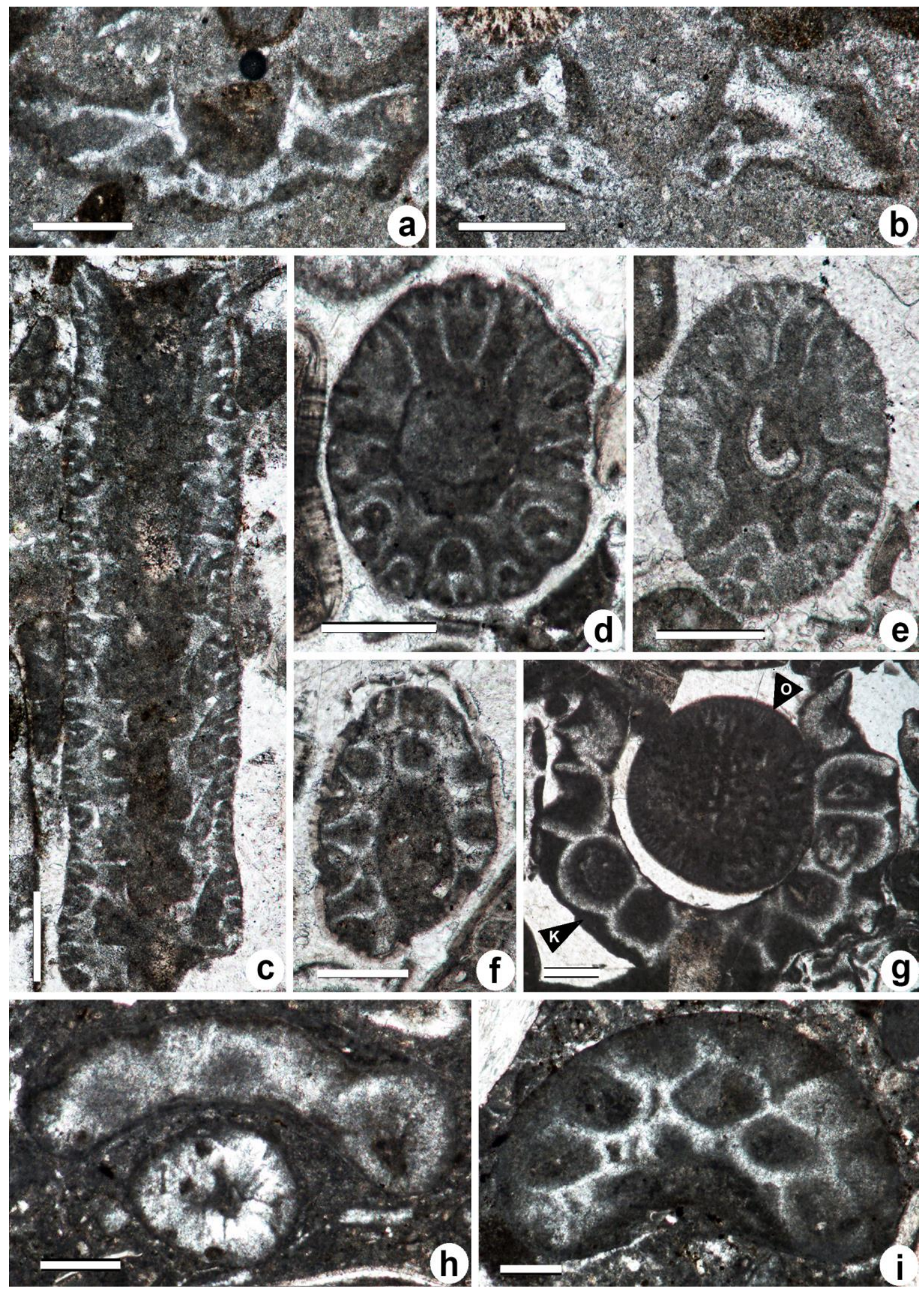

Fig. 7 Calcareous algae from the Tirgan Formation in the Gelian section. a, b Actinoporella podolica (Alth); oblique sections; sample G15. c-f Deloffrella quercifoliipora Granier \& Michaud; c, longitudinal-tangential section, sample G12; d-f, oblique sections, sample G16. g-i Kopetdagaria sphaerica Maslov; g (K) transverse section (O - orbitolinid foraminifer), sample G35; h, i, fragments of oblique sections; h, sample G32a; i, sample G32b. Scale bar is $0.25 \mathrm{~mm}$. 

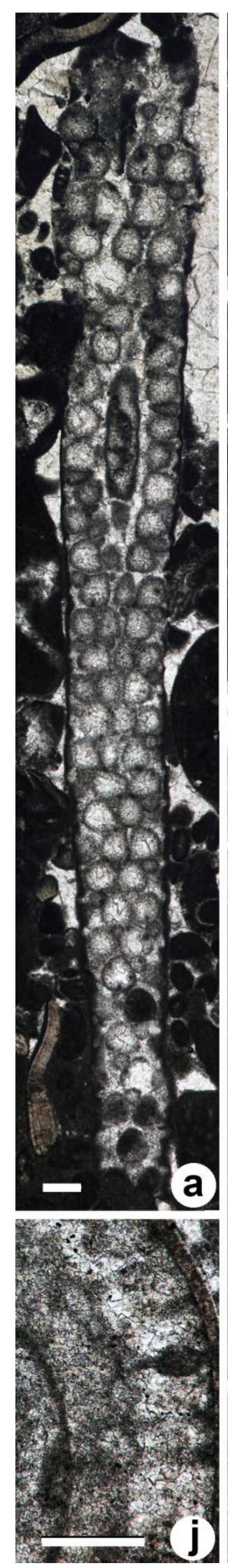
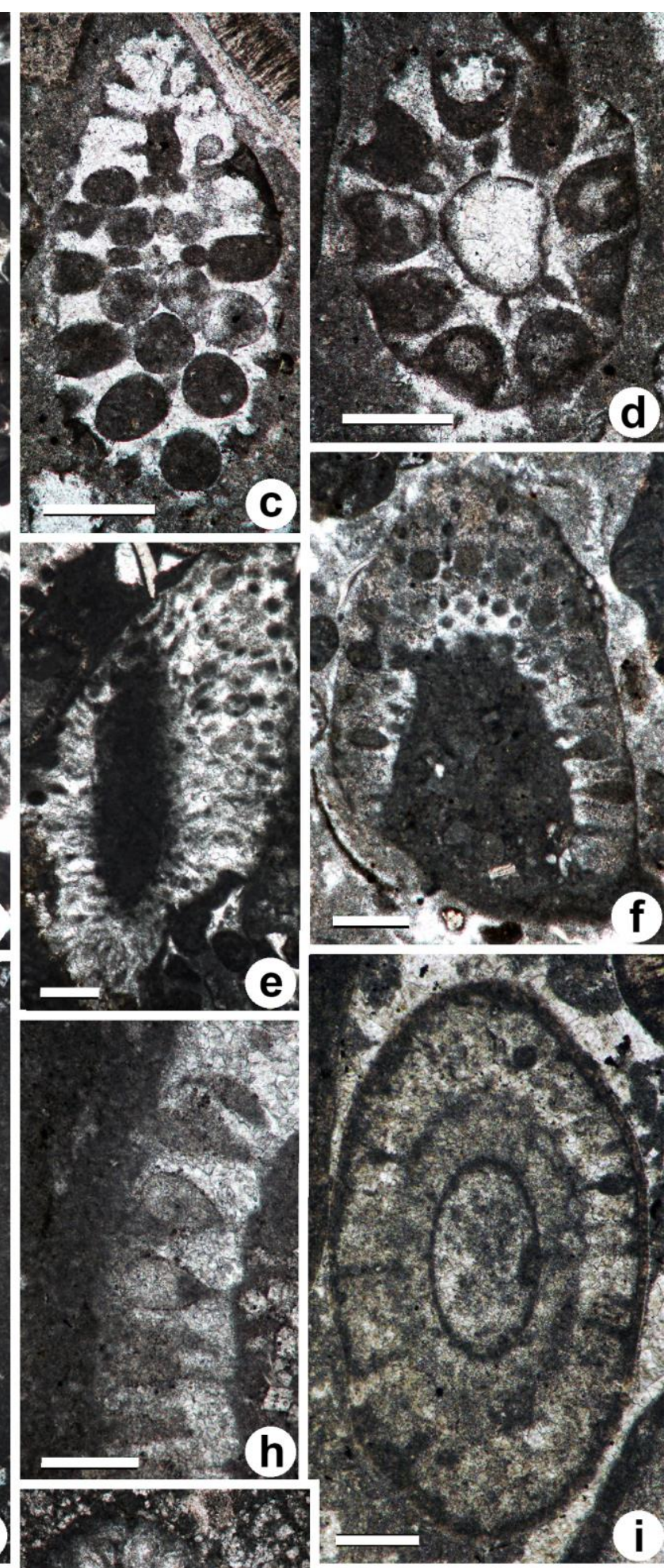

(g)
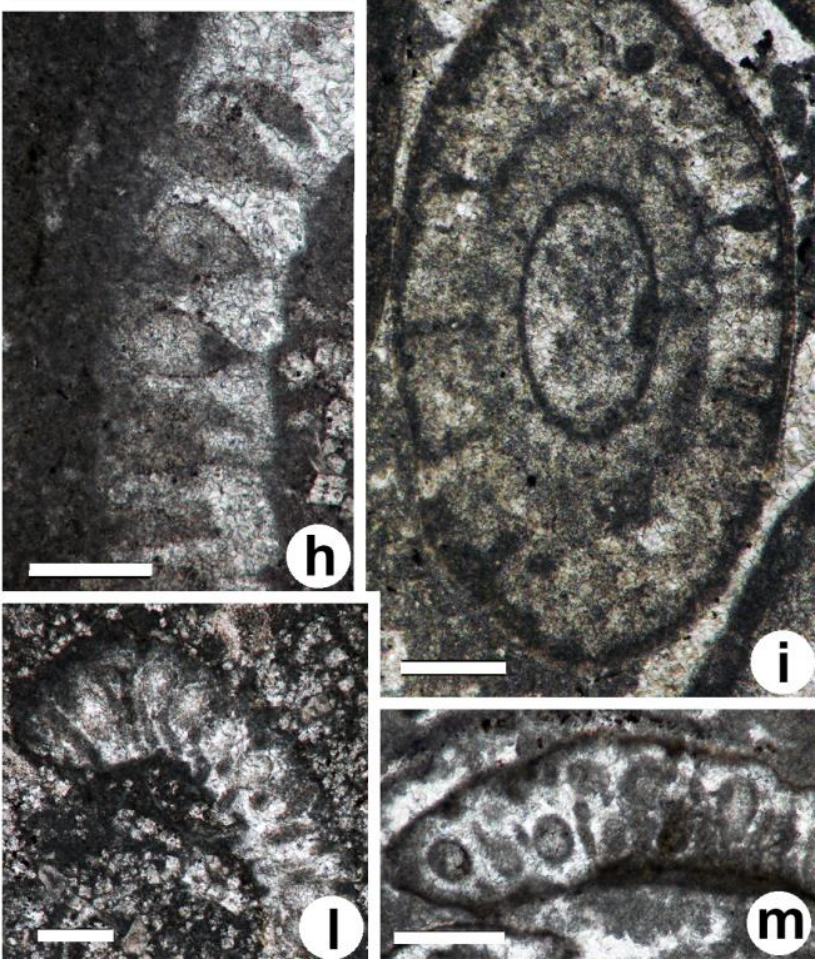

Fig. 8 Calcareous algae from the Tirgan Formation in the Gelian section. a-d Bakalovaella elitzae (Bakalova). a, b, longitudinal-oblique sections, sample G35; c, oblique section, sample G15; d, transverse-oblique section, sample G15. e-h Neomeris cf. cretacea Steinmann; e, oblique-tangential section, sample G35; f, g, oblique sections; h, detail of g showing the reproductive structures morphology; f sample G49; g, h, sample G34. i, j Neomeris sp. Oblique section; j - detail of i; sample G33. k-m Fragments of Neomeris ssp.; k, m, sample G16a; 1, sample G34. Scale b is 0.25 mm. 

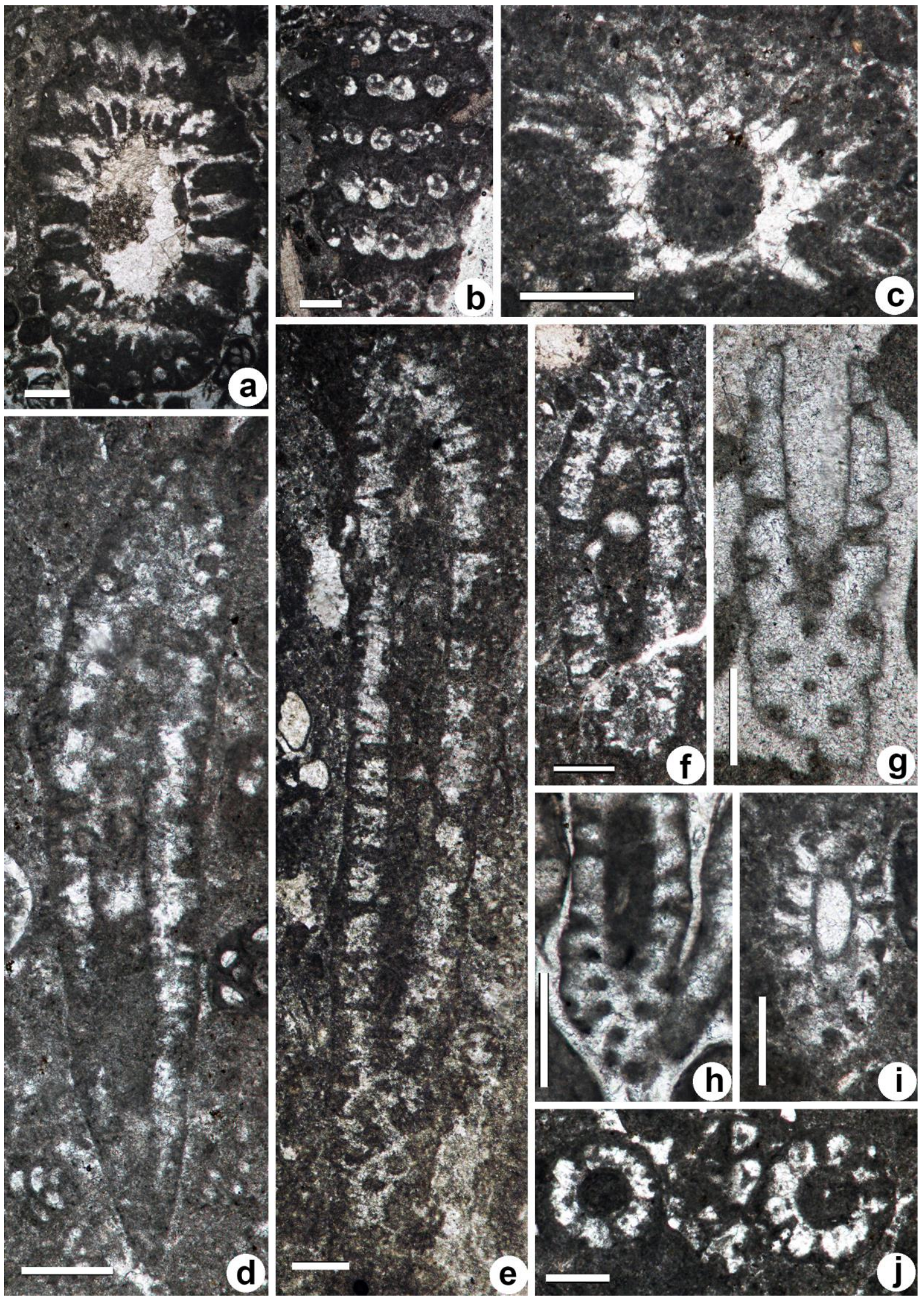

Fig. 9 Calcareous algae from the Tirgan Formation in the Gelian section. a-c Pseudoactinoporella? iranica Bucur, Rashidi \& Senowbari-Daryan; a, oblique section, sample G12; b, tangential section, sample G17a; c, transverse section, sample G27-28. dg, i Salpingoporella muehlbergii (Lorenz); d, e, longitudinal-oblique sections, sample G29; f. g, oblique sections; f, sample G29; g, sample G25; j, transverse section, sample G29. h, i Salpingoporella sp., oblique sections; h, G16; I, sample G29. Scale bar is $0.25 \mathrm{~mm}$. 


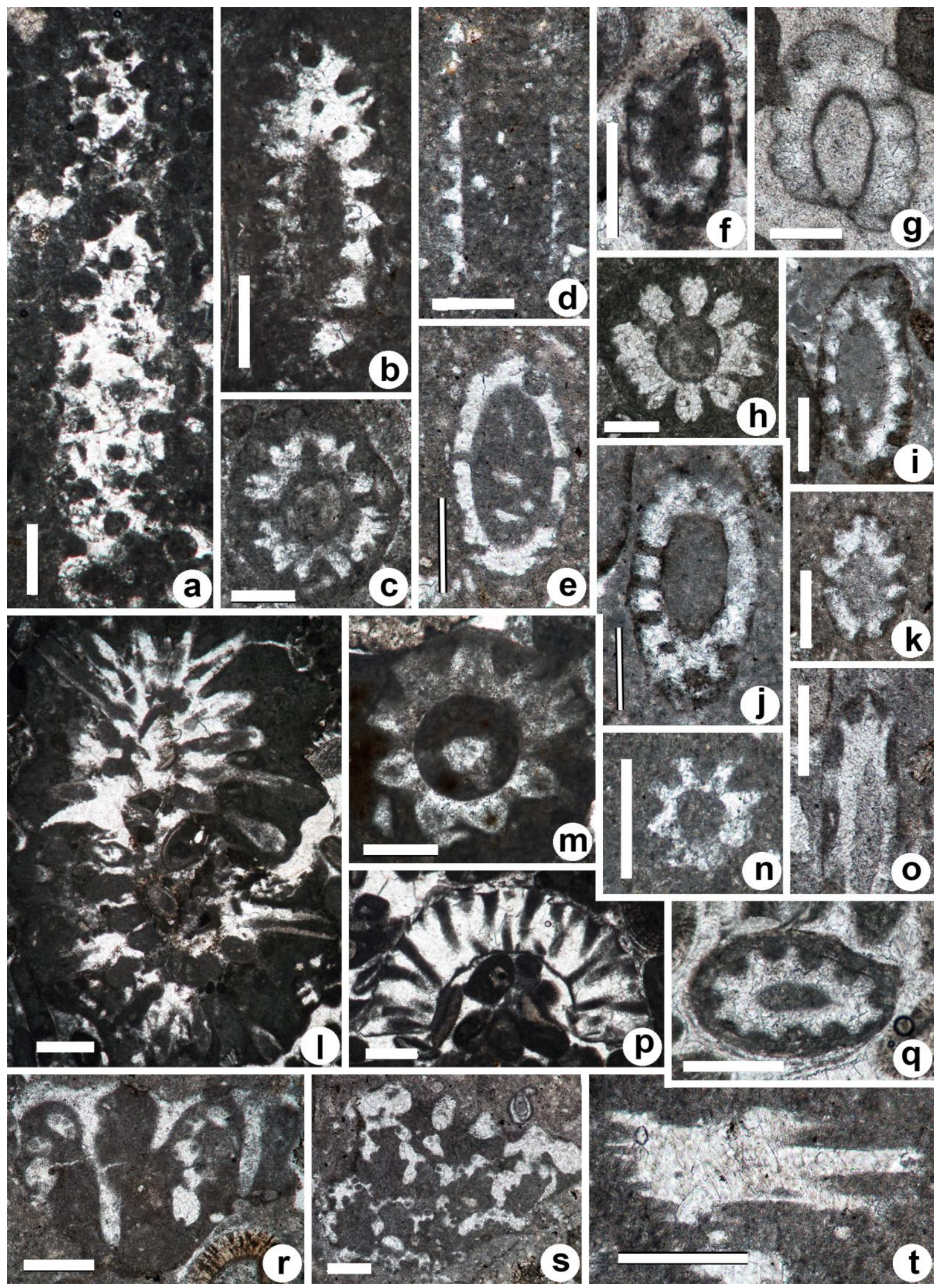

Fig. 10 Calcareous algae and microproblematica from the Tirgan Formation in the Gelian section. a-c, g, h Salpingoporella muehlbergii (Lorenz); a, tangential section, sample G32; b, oblique section, sample G32; c, transverse section, sample G29; g, oblique section, sample G25; h, transverse section, sample G29. d, e, f, i-k, n Salpingoporella div. sp. in longitudinal (d), oblique (e, f, i, j, k) and transverse (h, n) sections; d, sample G19; e, sample G21a; f, sample G17b; i-k, sample G15; n, sample G22. I, m Unidentified actinoporelliform dasycladalean alga; 1, oblique section, sample G16a; m, transverse section, sample G35. o, q, t Carpathoporella occidentalis Dragastan; different sections through supposed octocoralian sclerites; o, sample G15; q, sample G42; t, sample G32. p Steinmanniporella sp. transverse section, sample G35. r Triploporella sp., sample G15. s ?Zittelina sp, sample G15. Scale bar is $0.25 \mathrm{~mm}$. 

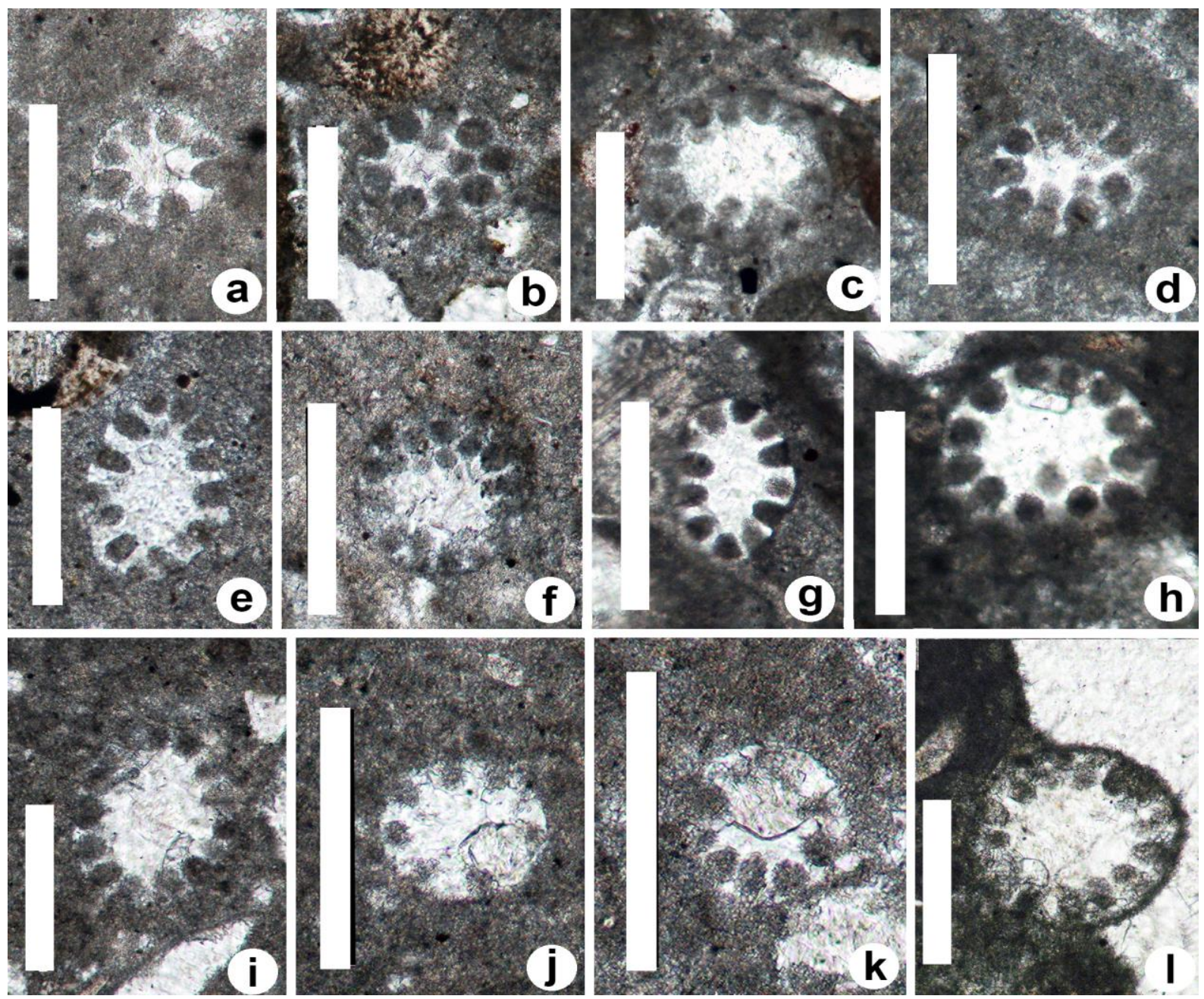

Fig. 11 Calcareous algae from Tirgan the Formation in the Gelian section. a-l Terquemella div. sp. a, j, k, sample G32; b, c, sample G12; d-f, 1, sample G15; g, sample G16a; h, sample G18a, I, sample G18b. Scale bar is 0.25 mm.

Formation. Later, Immel et al. (1997) have demonstrated the heterochronous nature of the Lower Cretaceous deposits from the Kopet Dagh basin based on rich ammonite faunas, and indicated a Hauterivian-late Barremian age for the Tirgan Formation in the western part of the Kopet Dagh basin, and a late Barremian to earliest Aptian age in the east. Recently, Molaei et al. (2019) reported an ammonite fauna from the Tirgan Formation in the Shar Abad section (NW Kopet Dagh). In this section, the middle and upper part of the Tirgan Formation are attributed to the upper Barremian (with Heteroceras sp.) and to lower Aptian (with Deshayesites cf. planus and Deshayesites cf. fobersi), respectively. These authors also mention that in a nearby area (Takal Kuh section) Raisossadat and Shakri (2011) identified an upper Barremian ammonite association (with Colchidites, Imerites, Barremites, Heteroceras) within the Sarcheshmeh Formation, a unit overlying the Tirgan Formation. However, Molaei et al. (2019) did not comment on the unusual age overlap between these two units, which normally have a superpositional relationship.

The heterochrony of the Tirgan Formation, as indicated by the available data, can be correlated with the facies variations and heterochrony of the Tithonian to lowermost Cretaceous formations from the Kopet Dagh basin.
This phenomenon, noted by Immel et al. (1997), and presumed by Majidifard (2003) and Majidifard et al. (2017), was demonstrated by Bucur et al. (2013). According to the latter authors, in the Takhtehbashgheh section, the upper part of the Mozduran Formation extends into the Valanginian. It can be assumed that in other sections the lowermost Cretaceous (Berriasian-Valanginian) could be developed in a carbonate facies underlying directly the carbonate deposits of the Tirgan Formation (see ArnaudVanneau et al., 2017). Further mapping together with detailed and accurate micropaleontological analyses are necessary in order to clarify these aspects. However, a rigorous review of the already described micropaleontological associations from the sections studied by different authors should also shed new light on the potential heterochrony of the Kopet Dagh Lower Cretaceous.

\section{REMARKS ON SELECTED MICROFOSSILS}

Pseudoactinoporella? iranica Bucur, Rashidi \& Senowbari-Daryan (Fig. 9a-c)

Bucur et al. (2012) described this dasycladalean alga from the Taft Formation in central Iran (at Aliabad, near Yazd). Figure 5 caption in Bucur et al. (2012, p. 611) indicates this species as Actinoporella? iranica. 

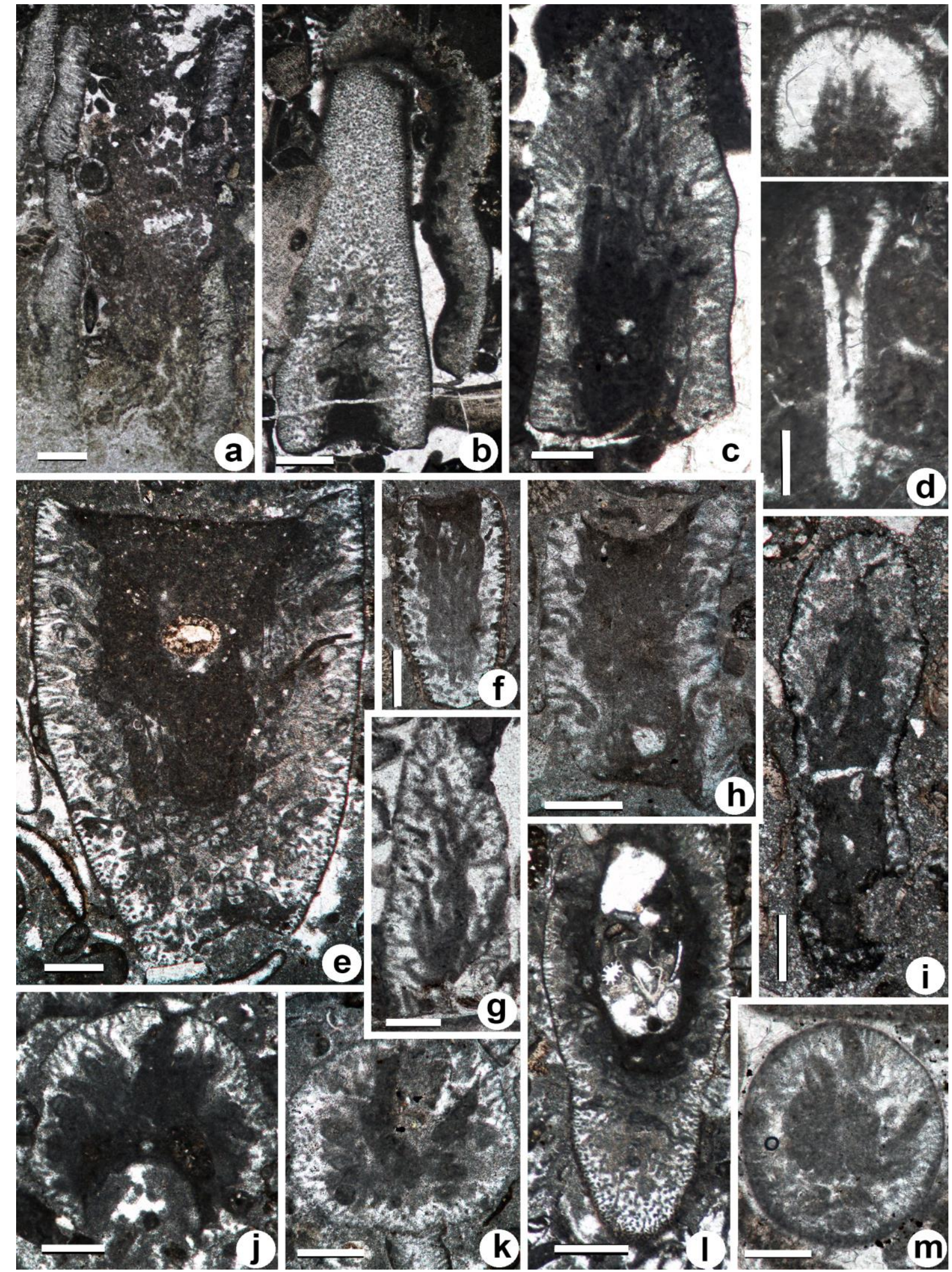

Fig. 12 Calcareous algae from the Tirgan Formation in the Gelian section. a, b Arabicodium sp. a, longitudinal section, sample G12; b, Oblique section, sample G35. c Boueina hochstetteri Toula; longitudinal-oblique section, sample G35. d Permocalculus (Pyrulites) deceneii Bucur; reconstruction based on 2 longitudinal-oblique sections, sample G18c. e, k-m Udoteacean-gymnocodiacean algae showing characteristics of both Boueina-Arabicodium, and Permocalculus: branching lateral and cortical filaments like in Boueina-Arabicodium, and large inflated filaments like the "reproductive structures" in Permocalculus; e, l, oblique sections; e, sample G15; 1, sample G16a; k, m, transverse sections; k, sample G16a; m, sample G33. f, g Boueina minima Bucur, Rashidi \& Senowbari-Daryan; f, longitudinal-oblique section, sample G15; g, oblique section, sample G16. h, i Boueina cf. pygmaea (Pia); longitudinal (h) and longitudinal-oblique (i) sections; h, sample G15; i, sample G13b. Scale bar is $0.25 \mathrm{~mm}$. 

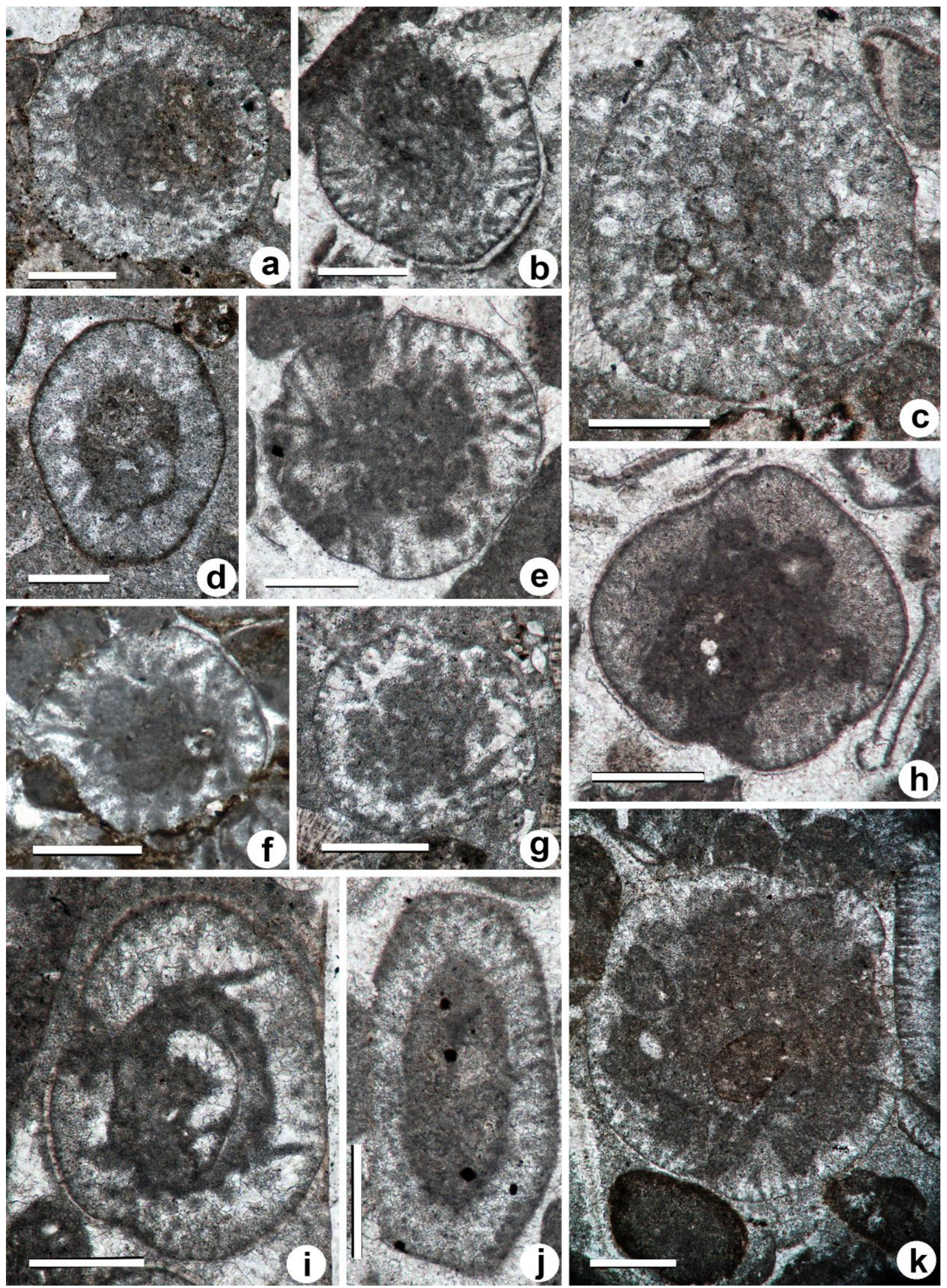

Fig. 13 Calcareous algae from the Tirgan Formation in the Gelian section. a, b, e-g, i Boueina cf. pygmaea (Pia); a, b, e, g, transverse sections; a, sample G13b; b, e, sample G16; f, g, sample G16a; i, oblique section, sample G17c. c Boueina hochstetteri Toula, transverse section, sample G17a. d Boueina minima Bucur, Rashidi \& Senowbari-Daryan, transverseoblique secton, sample G15. h, j, k Permocalculus sp.; transverse (h, k) and oblique (j) sections; h, sample G17b; j, sample G24a; k, sample G17a. Scale bar is $0.25 \mathrm{~mm}$. 

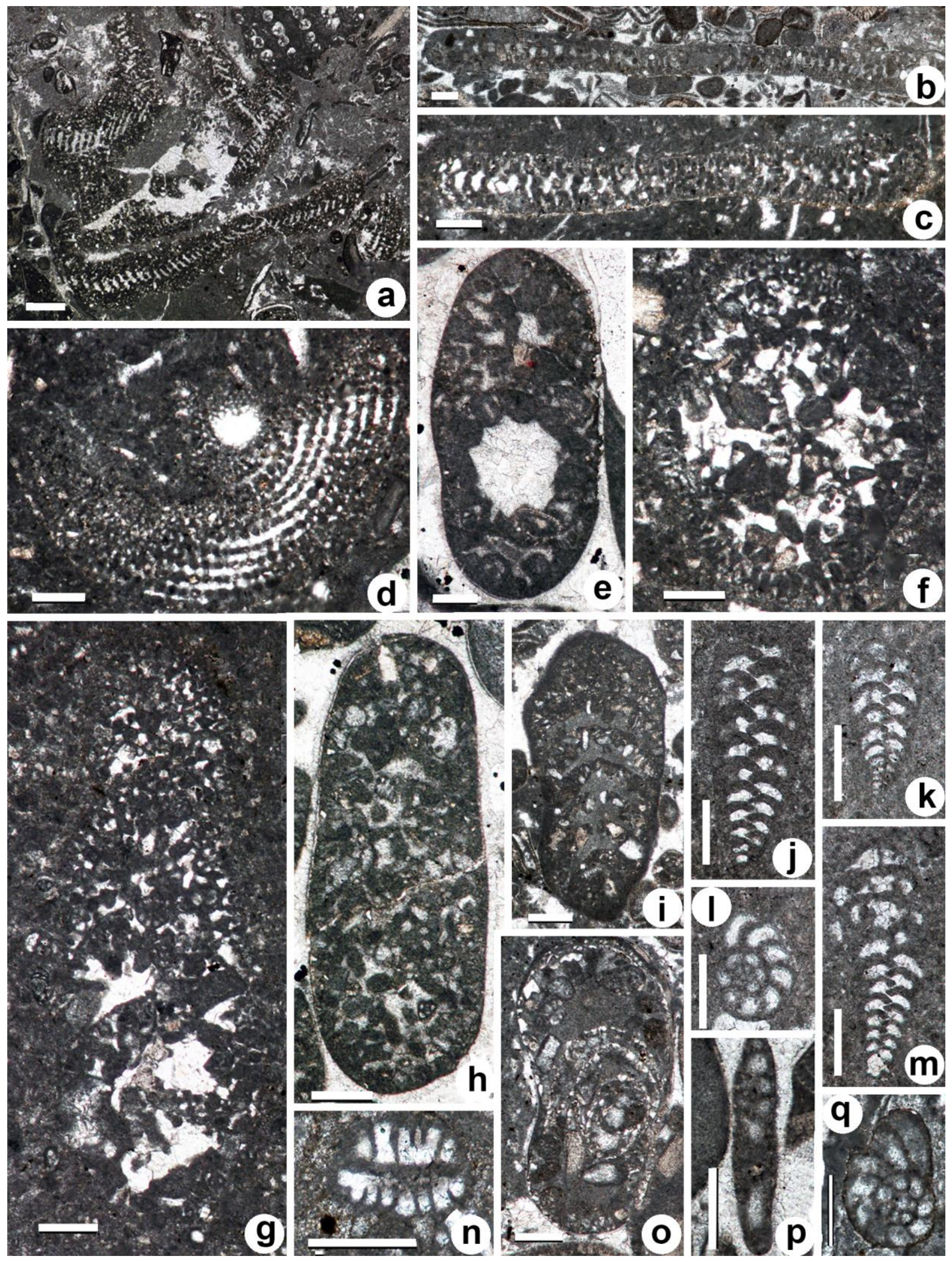

Fig. 14 Foraminifera from the Tirgan Formation in the Gelian section. a-d Balkhania balkhanica Mamontova. a, microfacies with Balkhania, sample G17a; b, c, subaxial transverse sections; b, sample G16a; c, sample G18; d, subequatorial section, sample G18. e-h Torremiroella hispanica Brun \& Canerot; e, oblique section of a megalospheric specimen cutting the proloculus, sample G23b; e, transverse section, sample G18; g-i, longitudinal-oblique sections; g, sample G28; h, sample G23b. i ?Reophax sp., sample G33; j, k, m, n Vercorsella scarsellai (DE Castro); j, k, m, longitudinal sections; j, sample G29; k, m, sample G31; n, transverse section, sample G30. l, p, q ?Mayncina sp., 1, sample G22; p, sample G17b; q, sample G16a. o ?Streptocyclammina sp., sample G33. Scale bar is $0.25 \mathrm{~mm}$. 
According to the ICBN rules, the first denomination mentioned in the text (Pseudoactinoporella? iranica, Bucur et al., 2012, p. 609) is the correct and valid one. Until now, Kopet Dagh represents the second area where this taxon was identified.

Bakalovaella elitzae (Bakalova) (Fig. 8a-d).

Initially described by Bakalova (1971) as Cylindroporella elitzae, this dasycladalean alga was subsequently attributed to the genus Montiella by Radoićič (1980). Bucur (1993) transferred it to the new genus Bakalovaella by highlighting some differences between the Cenozoic species of Montiella (M. munieri and M. macropora) and the Lower Cretaceous alga originally assigned to the genus Cylindroporella. However, numerous paleoalgologists avoided its attribution to the genus Bakalovaella and preferred to assign it to Montiella. Subsequently, some authors (Taherpour Khalil Abad et al., 2010; Bucur, 2011) questioned once more the attribution of the species elitzae to the genus Montiella, and recently Granier \& Bucur (2019) reinstated the genus Bakalovaella based on the species Bakalovaella deloffrei Granier \& Bucur, and revalidated the combination Bakalovaella elitzae (Bucur, 1993).

Boueina minima Bucur, Rashidi \& Senowbari-Daryan (Fig. 12f,g; Fig. 13d).

This udoteacean alga was also described from the Taft Formation by Bucur et al. (2012). Just as in the case of Pseudoactinoporella? iranica, it appears with two denominations: Boueina minima (in text, p. 625) and Boueina minuta (caption of Fig. 13) (Bucur et al., 2012, p. 627). Boueina minima is the correct denomination of this taxon since it is mentioned as such for the first time in the text. This species is now reported for the first time in carbonate deposits other than those from the type locality.

Udoteacean-gymnocodiacean algae showing characteristics of both Boueina-Arabicodium, and Permocalculus (Fig. 12e, j-m).

Some of the calcareous algae identified within the Tirgan Formation have ramified medullar and cortical filaments arranged in a manner similar to that described in Boueina and Arabicodium. At the same time, they also present a series of inflated, larger ovoid or ovoid-acuminated filaments. Such filaments are similar to the supposed reproductive organs of the gymnocodiacean algae. A similar alga is Boueina camenitzae (Dragastan \& Bucur, 1979) which contains such sub-ovoid filaments in the subcortical zone. When the inflated filaments are elongated, confusion with Juraella bifurcata is possible. A revision of these gymnocodiacean-udoteacean algae is currently undertaken by Bucur \& Schlagintweit.

Torremiroella hispanica Brun \& Canerot (Fig. 14e-h) Schlagintweit et al. (2013a) identified this foraminifer in central Iran; its presence in the Kopet Dagh basin is documented for the first time in this study, a report that does not influence its paleogeographical significance. Its cooccurrence with Balkhania balkhanica and Kopetdagaria sphaerica is highly expected (see Schlagintweit et al., 2013a). From a paleogeographic perspective, the Kopet
Dagh basin is integrated in the Carpathian-Cimmerian province (Taherpour Khalil Abad et al., 2013).

\section{CONCLUSIONS}

This study deals with the carbonate succession of the Tirgan Formation by analyzing its outcrop within the Gelian section, near Shirvan locality in the central part of the Kopet Dagh basin. The latest Barremian to early Aptian age of these deposits is indicated by a rich micropaleontological assemblage consisting primarily of calcareous algae and benthic foraminifera, including orbitolinids, a result that is in accordance with the outcomes of previous micropaleontological studies. However, there are clear discrepancies in terms of age constraints between the Tirgan Formation and the overlying Sarcheshmeh Formation. The age of the first unit is defined mainly based on calcareous microfossils, whereas ammonite associations were used to determine the age of the second, overlying unit. Moreover, some authors assign a late Barremian to early Aptian age to the Sarcheshmeh Formation (Immel, 1997; Raisossadat and Shakri, 2011). Such an age attribution produces overlaps with the orbitolinid-based age assessments of the Tirgan Formation. As a consequence, one should presume that these formations are heterochronous along the Kopet Dagh basin. The exact and detailed patterns and underlying mechanisms of such a heterochrony are yet to be understood.

\section{ACKNOWLEDGEMENTS}

We thank the reviewers Felix Schlagintweit and Mike Kaminski, and the editor Zoltan Csiki for their remarks and corrections, which contributed greatly to the improvement of the manuscript. We also thank the editor Iuliana Lazăr and assistant editor Mihaela Grădinaru for editorial help, allowing a quick publication of the paper.

\section{REFERENCES}

Afshar Harb, A., 1979. The stratigraphy, tectonics and petroleum geology of the Kopet Dagh region, northern Iran. PhD Thesis, University of London, London, $316 \mathrm{pp}$.

Arnaud-Vanneau, A. \& Schroeder, R., 1976. Paleodictyoconus actinostoma n. sp. Orbitolinidae nouveau des "Couches á orbitolines" intra-urgoniennes du Vercors (France). Géobios, 9 (3): 279-289.

Arnaud-Vanneau, A., Gheiasvand, M., Fölmi, K.B., Adatte, T., Spangerberg, J.E., 2017. Définition d'une formation carbonate crétacée en Iran: La Formation Tirgan. In: Desmares, D. and Grosheny, D. (eds) Reunion thématique du Group Francais du CrétacéQuoi de neuf au Crétacé?, Paris les 4 et 5 décembre 2017. Volume de résumés, pp. 11.

Bakalova, D., 1971. Nouvelles espèces de Dasycladaceae (Algae) dans les sediments urgoniens du Prébalkan central. Bulgarian Academy of Sciences, Bulletin of the Geological Institute, series Paleontology, 20:123128.

Brunet,M.F., Korotaev, M.V., Ershov, A.V., Nikushin, A.M., 2009.The South Caspian Basin: a review of its 
evolution from subsidence modelling. Sedimentary Geology, 156: 119-148.

Bucur I.I., 1993. Some new or poorly known calcareous algae (Dasycladales, Gymnocodiaceae) in the Lower Cretaceous deposits from the Reşiţa-Moldova Nouă zone (Southern Carpathians, Romania). Revista Española de Micropaleontologia, 25 (1): 93-126.

Bucur, I.I., Majidifard, M.R., Senowbari-Daryan, B., 2013. Early Cretaceous calcareous benthic microfossils from the Eastern Alborz and western Kopet Dagh (Northern Iran) and their stratigraphic significance. Acta Palaeontologica Romaniae, 9 (1): 23-37.

Bucur,I.I., Rashidi, K., Senowbari-Daryan, B., 2012. Early Cretaceous calcareous algae from central Iran (Taft Formation, south of Aliabad, near Yazd). Facies, 58: 605-636.

Bucur I.I., 2011. Early Barremian dasycladalean algae from Serre de Bleyton(Drôme, SE France). Annalen des Naturhistorischen Museums in Wien, Serie A, 113: 619-653.

Carević, I., Taherpour Khalil Abad, M., LjubovićObradović, D., Vaziri, S.H., Mirković, M., Aryaei, A.A., Stejić, P., Ashouri, A.R., 2013. Comparisons between the Urgonian platform carbonates from eastern Serbia (Carpatho-Balkanides) and northeast Iran (Kopet Dagh basin): Depositional facies, microfacies, biostratigraphy, palaeoenvironments and palaeoecology. Cretaceous Research, 40: 110-130.

Dragastan, O. \& Bucur, I.I., 1979. Upper Aptian microfossils from the Cameniţa Valley - Sasca Română (Reşiţa-Moldova Nouă zone, Banat. Révue Roumaine de Géologie, Géophysique, Géography, Géologie 23 (1): 111-115.

Fürsich, F.T., Wilmsen, M., Seyed-Emami, K., Majidifard, M.R., 2009. The mid-Cimmerian tectonic event (Bajocian) in the Alborz Mountains, Northern Iran: evidence of the break-up unconformity of the Caspian Basin. In: Brunet, M.-F., Wilmsen, M., Granath, J. W. (eds) South Caspian to Central Iran Basins. Geological Society of London, Special Publication 312, pp.189-203.

Granier, B., Clavel, B., Moullade, M., Busnardo, R., Charollais, J., Troncheti, G., Desjaques, P., 2013. L'Estellon (Baronnies, France),a "Rosetta Stone" for the Urgonian biostratigraphy. Carnets de Géologie/Notebooks on Geology, Article 2013/04 (CG2013_04): 163-207.

Granier, B. \& Bucur, I.I., 2019. Le genre Bakalovaella BUCUR, 1993 (Dasycladeae, Dasycladaceae), et description de son plus ancien représentant crétacé. Carnets de Géologie, 19 (1): 1-19.

Immel, H., Seyed-Emami K., Afshar-Harb A., 1997. Kreide-Ammoniten aus dem iranischen Teil des Koppeh-Dagh (NE-Iran). Zitteliana, 21: 159-190.

Javanbakht, M., Moussavi-Harami, R., Mahboubi, A., 2011. Depositional history and sequence stratigraphy of the Tirgan Formation (Barremian-Aptian) in the Zavin section, NE Iran. Iranian Journal of Earth Sciences, 3:108-118.

Javanbakht, M., Wans, H.A., Jafarian, A., Shahsavan, N., Sahraeyan, M., 2018. Carbonate diagenesis in the Barremian-Aptian Tirgan Formation (Kopet-Dagh Basin, NE Iran): Petrographic, geochemical and res- ervoir quality constraints. Journal of African Earth Sciences, 144: 122-135.

Kavoosi, M.A., Lasemi, I., Sherkati, S., MoussaviHarami, R., 2009. Facies analysis and depositional of the Upper Jurassic Mozduran Formation, a carbonate reservoir in the Kopet Dagh basin, NE Iran. Journal of Petroleum Geology, 32 (3): 235-260.

Majidifard, M.R., 2003. Biostratigraphy, Lithostratigraphy, ammonite taxonomy and microfacies analysis of the Middle and Upper Jurassic of norteastern Iran. PhD Thesis, Julius Maximilians Universität Würzburg, Würzburg, 201 pp.

Majidifard, M.R., Fürsich, F.T., Keupp, H., SeyedEmami, K., 2017. Lower Tithnian ammonites from the Chaman Bid Formation in northeastern Iran, Koppeh Dagh Basin. Geopersia, 7 (1): 11-26.

Mancinelli, A. \& Chiocchini, M., 2006. Cretaceous benthic foraminifers and calcareous algae from Monte Cairo (southern Latium, Italy). Bollettino della Socieatà Paleontologica Italiana, 45 (1): 91-113.

Masse, J.-P., 2003. Integrated stratigraphy of the lower Aptian and applications to carbonate platforms: a state of the art. In: Gili E. et al. (eds) North Africa Cretaceous carbonate platform systems, Kulver Academic Publishers, Amsterdam, 203-214.

Molaei, M., Vaziri, S.H., Taherpour Khalil Abad, M., Taheri, J., 2017. Early Cretaceous Neotrocholina Reichel, 1956 from the Tirgan Formation, Kopet Dagh sedimentary basin, NE Iran: systematic and biometric interpretation. Arabian Journal of Geosciences, 10: 317.

Molaei, M., Vaziri, S.H., Raisossadat, S.N., Taherpour Khalil Abad, M., Taheri, J., 2019. Late BarremianEarly Aptian ammonites from the Tirgan Formation, Kopet-Dagh sedimentary basin, NE Iran. Journal of sciences, Islamic Republic of Iran, 30 (1): 51-59.

Moussavi-Harami, R. \& Brenner, R.L., 1993. Diagenesis of non-marin petroleum reservoirs: the Neocomian (Lower Cretaceous) Shurijeh Formation, Kopet-Dagh Basin, NE Iran. Journal of Petroleum Geology, 16 (1): 55-72.

Nadim, H. \& Haftlang, R., 2009. Geological map of Iran, scale 1:100.000, Shirvan sheet. Geological Survey and Mineral Explorations of Iran.

Radoicćič, R., 1980. Contribution to the reconsideration of a group of cylindroporelliform dasyclads. Bulletin de l'Académie Serbe des Sciences et des Arts, Classe Sciences naturelles et mathematique, Sciences naturelles 72 (20): 109-115.

Raisossadat, N. \& Moussavi-Harami, R., 2000. Lithostratigraphic and facies analyses of the Sarcheshmeh Formation (Lower Cretaceous) in eastern Kopet Dagh Basin, NE Iran. Cretaceous Research, 21: 507-516.

Raisossadat, N. \& Shokri, M.H., 2011. Biostratigraphic studies of the Lower Cretaceous (upper Barremianlower Aptian) Sarcheshmeh and Sanganeh formations in the Kopet Dagh Basin, NE Iran: an integration of the calcareous nannofossils and ammonites stratigraphies. Stratigraphy and Geological Correlation, 12 (2): 188-204.

Robert, A.M.M., Letouzey, J., Kavoosi, M.A., Sherkati, S., Müller, C., Vergés, J., Aghababaei, A., 2014. 

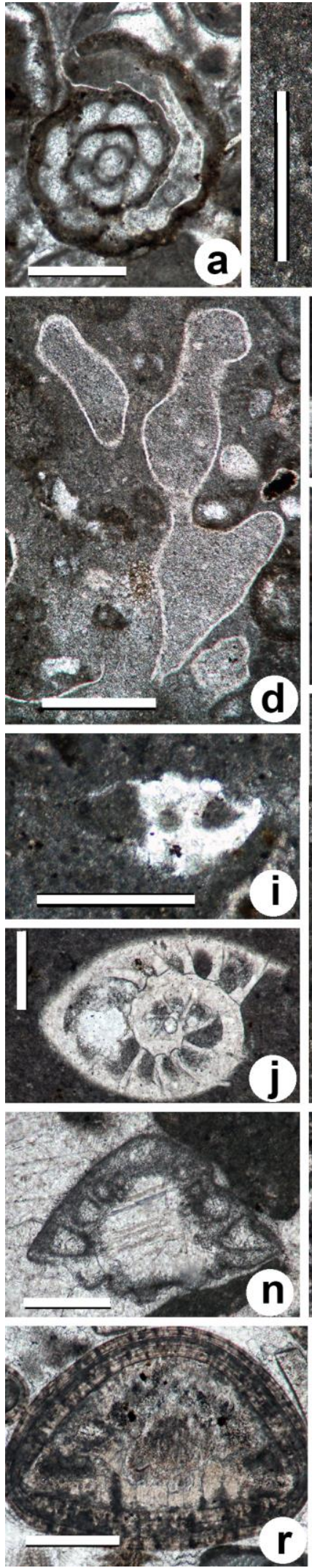
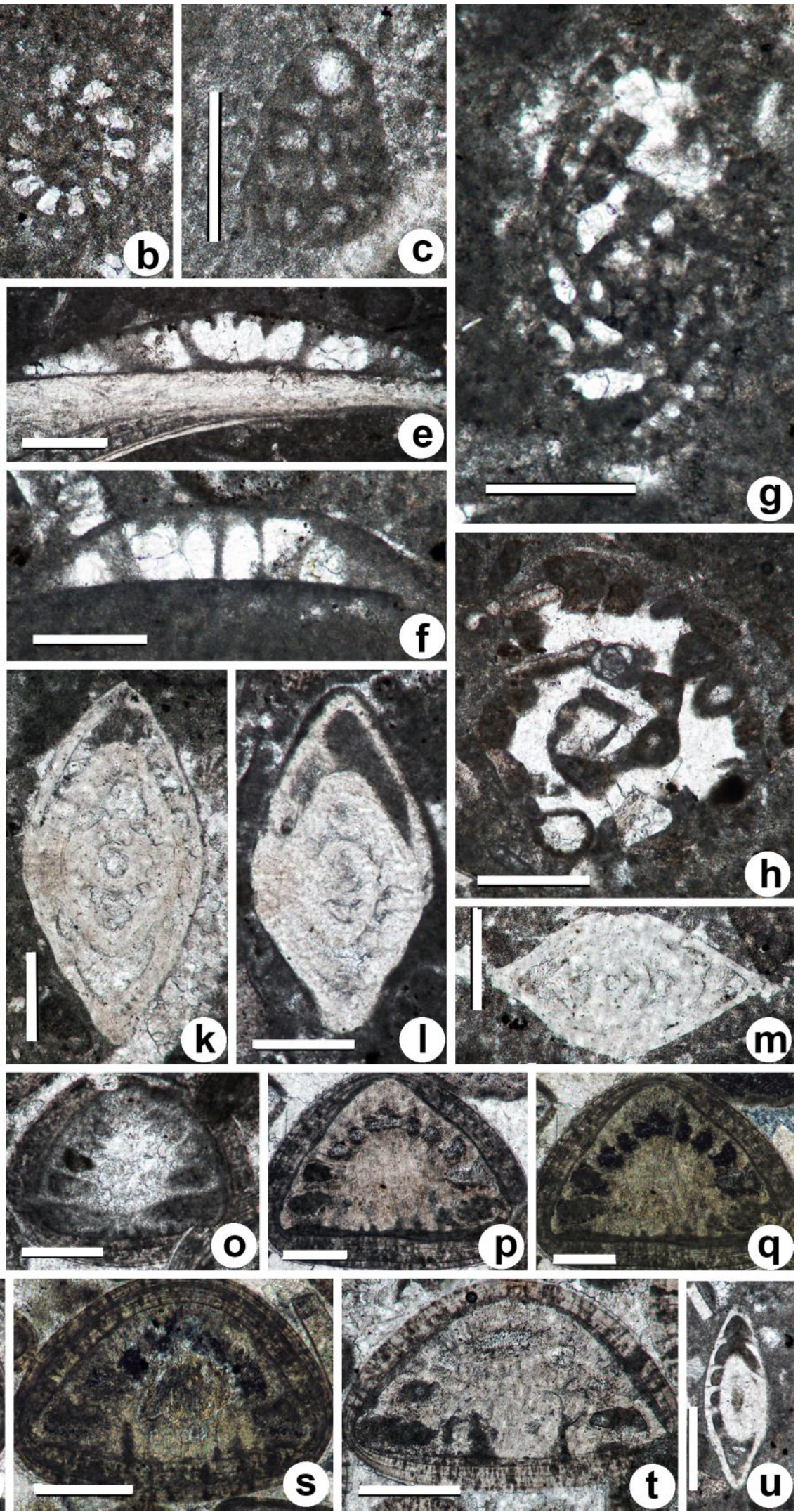

Fig. 15 Foraminifera from the Tirgan Formation in the Gelian section. a Charentia cuvillieri Neumann, equatorial section, sample G16a. b Nautiloculina sp., equatorial section, sample G32. c Vercorsella sp., longitudinal-tangential section, sample G29. d Bullopora sp., sample G17a. e, f Encrusting foraminifer, sample G32a. g, h Unidentified agglutinating foraminifera; g, sample G18; h, sample G46. i Epistominid foraminifer, axial section, sample G44b. j-m, u Lenticulina sp. in subequatorial (j) and axial-subaxial (k-m, u) sections; j, sample G50; k, sample G32b; l, m, sample G45; u, sample G48. n, ?o Frentzenella cf. odukpaniensis (Desauvagie), longitudinal sections; n, sample G24a; o, sample G39a. p-t Neotrocholina aptiensis (Iovcheva), longitudinal and oblique sections; p, q, sample G29b (q with cross nikols); r, s, sample G42 (s with cross nikols); t, sample G42a. Scale bar is $0.25 \mathrm{~mm}$. 

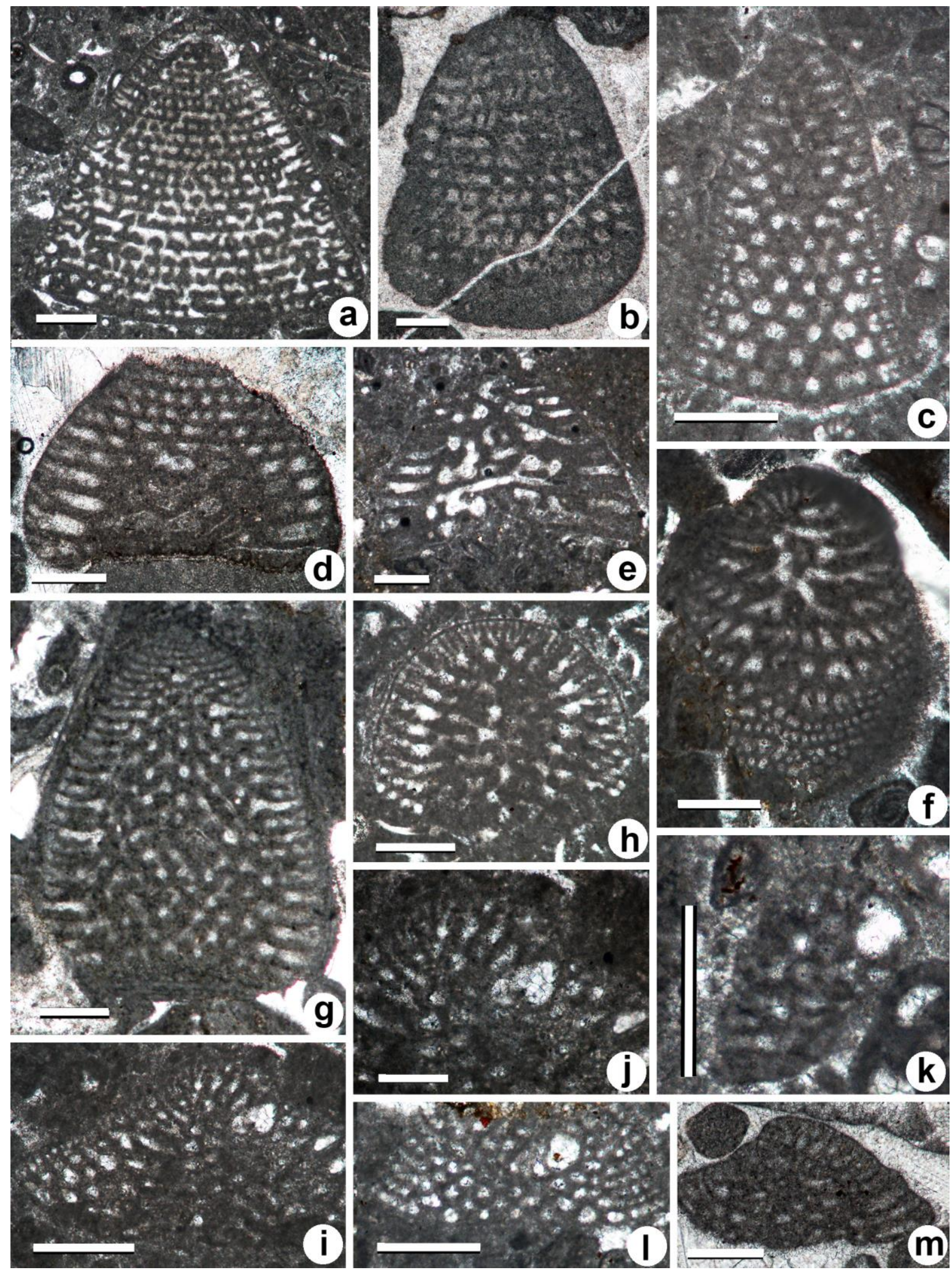

Fig. 16 Orbitolinid foraminifera from the Tirgan Formation in the Gelian section. a Rectodyctioconus giganteus Schroeder, longitudinal section, sample G29; b Montseciella arabica (Henson)longitudinal-oblique section; sample G25; c ?Iraqia sp., sample G32. e-f Dictyoconus? pachymarginalis Schroeder, longitudinal-oblique sections; e, sample 32; f, sample G35. d, g, h ?Orbitolinopsis sp., oblique (d), longitudinal-oblique (g), and transverse-oblique (h) sections; d, sample G23a; g, sample G35; h, sample G32. i-l Praeorbitolina cormyi Schroeder; different sections cutting the embryonal apparatus; i, l, sample G32; j, close-up view of the embryonal apparatus in i; k, sample G29. m ?Paleodictyoconus sp., longitudinal-oblique section, sample G24a. Scale bar is $0.25 \mathrm{~mm}$. 

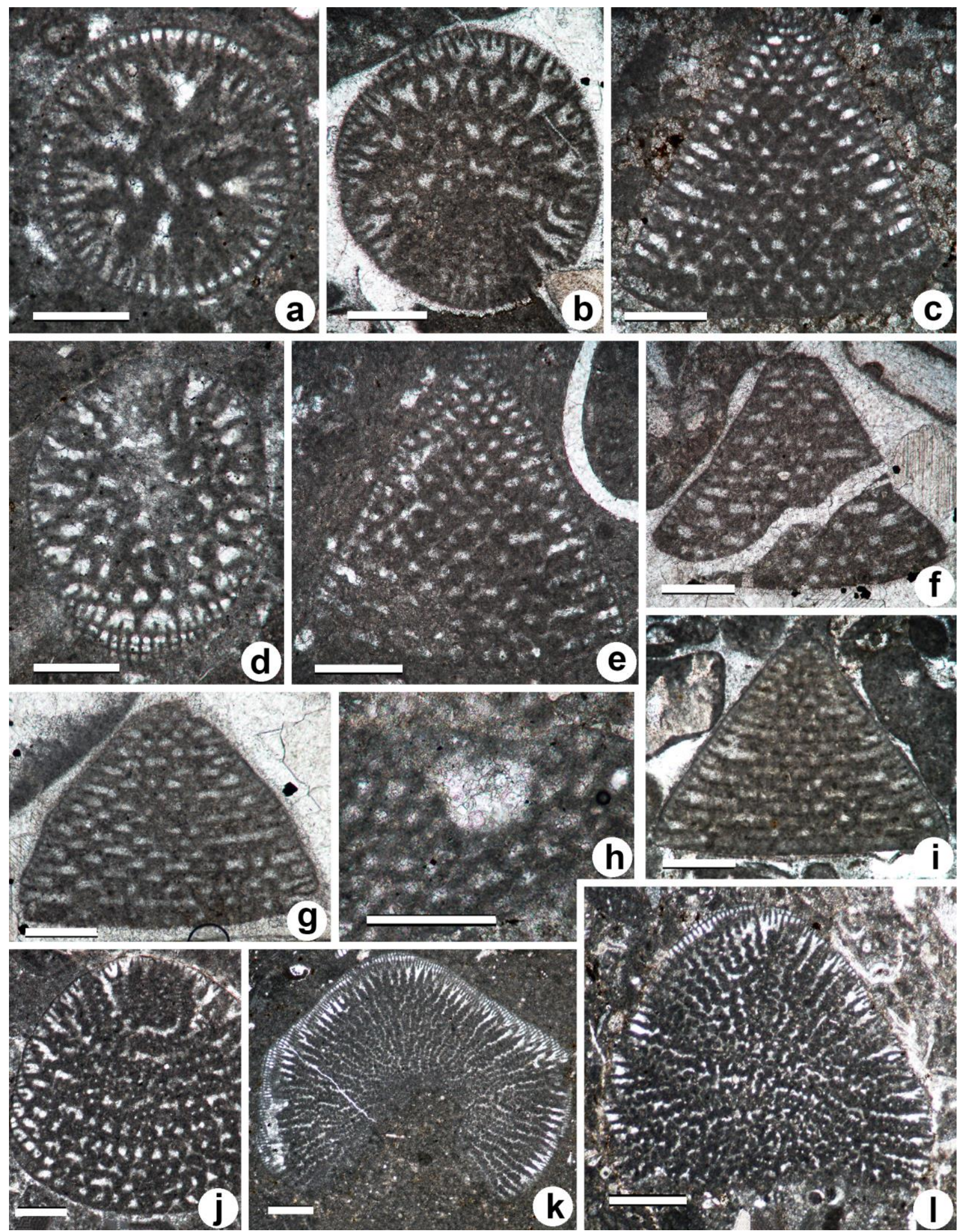

Fig. 17 Orbitolinid foraminifera from the Tirgan Formation in the Gelian section. a, c-e Iraqia simplex Henson; a, d, transverse and transverse-oblique sections; c, e, longitudinal and longitudinal-oblique sections; a, sample G32; c-e sample G30. b, f, g, i ?Iraqia sp.; b, sample G23a; f, g, sample G23b; i, sample G35. h Palorbitolina lenticularis Blumenbach, section through the embryonal apparatus, sample G47. j-1 Paleodictyoconus actinostoma Arnaud-Vanneau \& Schroeder; longitudinaloblique (j) and transverse oblique ( $\mathrm{k}, 1)$ sections; j, sample G29; $\mathrm{k}$, sample G44b; 1, sample G47. Scale bar is $0.25 \mathrm{~mm}$. 
Structural evolution of the Kopet Dagh fold-and-thrust belt (NE Iran) and interactions with the south Caspian Sea Basin and Amu Darya Basin. Marine and Petroleum Geology, 57: 68-87.

Ruttner, A.W., 1991. Geology of the Aghdarband area (Kopet Dagh, NE-Iran). In: Ruttner, A.W (ed) The Triassic of Aghdarband (AqDarband), NE-Iran, and its Pre-Triassic frame. Abhandlungen der Geolologischen Bundesanstalt, 38: 7-79.

Schlagintweit, F., Bucur I.I., Rashidi, K., Hanifzadeh, R., 2013a. Torremiroella hispanica Brun and Canerot, 1979 (benthic foraminifera) from the Lower Cretaceous of Central Iran and its palaeobiogeographic significance. Cretaceous Research, 46: 272-279.

Schlagintweit, F., Bucur I.I., Rashidi, K., Saberzadeh, B., 2013b. Praeorbitolina claveli n. sp. (benthic foraminifera) from the lower Aptian (Bedoulian) of Central Iran. Carnets de Géologie/Notebooks on Geology, Letter 2013/04 (CH2013_L04): 255-272.

Schroeder, R., 1965. Dictyoconus pachymarginalis n. sp. aus dem Apt des Alburz Gebirges (Nord-Iran (Studien über primitive Orbitolinidae III). Eclogae Geologicae Helvetiae, 58 (2): 975-980.

Schroeder, R., van Buchem F.S.P., Cherchi, A., Baghbani, D., Vincent, B., Immenhauser, A., Granier, B., 2010. Revised orbitolinid biostratigraphic zonation from the Barremian-Aptian of the eastern Arabian Plate and implications for regional stratigraphic correlations.GeoArabia Special Publication 4 (1): 49 96.

Stoecklin, J., 1968. Structural history and tectonics of Iran: a review. The American Association of Petroleum Geologists Bulletin, 52 (7): 1229-1258.

Taherpour Khalil Abad, M., 2017. Salpingoporella (Dasycladalean algae) species from the Lower Cretaceous carbonate facies of Kopet Dagh basin (NE Iran). Arabian Journal of Geosciences, 10:31.

Taherpour Khalil Abad, M., Conrad M.A., Aryaei, A.A., Ashouri, A.R., 2010a. Barremian-Aptian dasycladalean algae, new and revisited, from the Tirgan Formation in the Kopet Dagh, NE Iran. Carnets de Géologie/Notebooks on Geology, Article 2010/05 (CG2010_A05): 1-13.

Taherpour Khalil Abad, M., Aryaei, A.A., Ashouri, A., Hosseini S.A., 2010b. Benthic foraminiferal asseblages in Tirgan Formation (Urgonian facies type), west of Kopet-Dagh sedimentary basin, NE of Iran. Proceedings of the $1^{\text {st }}$ International Applied Geological
Congress, Department of Geology, Islamic Azad University - Mashad Branch, pp. 1027-1032.

Taherpour Khalil Abad, M., Schlagintweit, F., Ashouri, A., Aryaei, A.A., 2009. Juraella bifurcate Bernieir, 1984 (Calcareous alga, Gymnocodiaceae?) from the Lower Cretaceous (Barremian) Tirgan Formation of the Kopet Dagh basin, north-east Iran. Journal of Alpine Geology, 51: 79-86.

Tahepour Khalil Abad, M., Schlagintweit, F., Vaziri, S.H., Aryaei, A.A., Ashouri, A.R., 2013. Balkhania balkhanica Mamontova, 1966 (benthic foraminifera) and Kopetdagaria sphaerica Maslov, 1960 (dasycladalean alga) from the Lower Cretaceous Tirgan Formation of the Kopet Dagh mountain range (NE Iran) and their palaeobiogeographic significance. In: Bucur .I.I. and Fürsich F.T. (eds) Recent advances in fossil algae, Facies, 59 (1), pp. 267-285.

Tahepour Khalil Abad, M., Vasiri, S.H., Ashouri, A.R., 2015.Palorbitolina lenticularis, and index taxon from Tethyan basin and its biometric factors from Kopet Dagh Basin, NE Iran. Journal?

Wilmsen, M., Fürsich, F.T., Seyed-Emami, K., Majidifard, M.R., Taheri, J., 2009. The Cimmerian orogenyin northern Iran: tectono-stratigraphic evidence from the foreland. Terra Nova, 21: 211-218.

Yavarmanesh, H., Vaziri, S.H., Aryaei, A.A., Jahani D., Porkermani, M., Bouriabadi, E.H., 2017. Benthic foraminiferal and calcareous algae assemblages in the Tirgan Formation (Urgonian facies type) in south flank of Ghorogh syncline (north of Chenaran), NE Iran. Open Journal of Geology, 7: 796-805.

Yazdi-Moghadam, M., Sarfi, M., Sharifi, M., Ariafar, B., Sajjadi, F., Abbasi, P., 2017. Early Barremian orbitolinid record from the Moghan area, NW Iran: Northern margin of the Neotethys. Creataceous Research, 77: 133-142.

Zanchi, A., Zanchetta, S., Garzanti, E., Balini, M., Berra, F., Mattei, M., Muttoni, G., 2003. The Cimmerian evolution of the Nakhlak-Anarak area, Central Iran, and its bearing on the reconstruction of the history of the Eurasian margin. In: Brunet, M.F., Wilmsen, M., Granath, J.W. (eds) South Caspian to Central Iraan Basin. Geologica Society London, Special Publications, 312, pp. 261-286. 